\title{
TWITTER AS A CUSTOMER SERVICE MANAGEMENT PLATFORM: A STUDY ON INDIAN BANKS
}

\author{
Dr. Moonis Shakeel \\ Associate Professor, Department of Economics \\ Jamia Millia Islamia (A Central University), New Delhi, India \\ Sunil Barsaiyan \\ Research Scholar, Jaypee Business School \\ Jaypee Institute of Information Technology (A Deemed University), Noida, India \\ Dr. Charu Sijoria \\ Assistant Professor, Jaypee Business School \\ Jaypee Institute of Information Technology (A Deemed University), Noida, India
}

\begin{abstract}
In this study customer behavior on Twitter for the five private commercial Banks in India has been explored through the analysis of historical user Tweets. Lexicon-based sentiment analysis has been done to explore frequently used terms on the Tweets and Time-series plots have been generated to determine the flow of user sentiments. T-Test for Two-Sample Assuming Unequal Variance has been used to identify the significance of the sentiment type for each Bank. Results have indicated unique insights about the customer behavior like "Significance of Sentiments on Engagement", "Pattern of Tweeting and Timings", "Impact of Bank's activities on sentiments". This study suggests ways to handle negative Tweets and emphasizes on the need for media monitoring tools for the timely discovery of Tweets. The study also fills multiple gaps by exploring the behavior of customer's negative sentiments, the impact of grievances in creating and sharing eWOM, and Twitter use behavior.
\end{abstract}

Keywords: Customer Service, India, Banks, Twitter, Social Media.

\section{INTRODUCTION}

Customer Service Management (CSM) is a business process that primarily deals with the servicing of existing customers. With an increase in market competition, CSM has emerged as an important part of the organization's overall strategy. Christopher et al. (1991) have called customer service, a part of marketing strategy while Meltzer (2001) has claimed that organizations can boost profits by up to $100 \%$ just by retaining $5 \%$ of their most valuable customers which can be achieved through excellent customer service management. Efficient customer service leads to enhanced customer satisfaction which in turn can generate higher revenue for the organizations. Researchers like (Ahmad and Kamal, 2002), (Cronin and Taylor, 1992), in their respective studies, have emphasized that service quality is the antecedent to satisfaction. Satisfied customers turn loyal customers for an organization and positively impact others Hoyer et al. (2001).
A study done by Nwulu and Nwokah (2018) has revealed that customer service management directly impacts sales growth, market share, and profitability of an organization. Businesses are now more customer-centric than product-centric hence prioritizing relations with customers can boost profits and revenue for the organizations (Soltani et al., 2018). Innovations and new technologies have brought new capabilities to the service organizations (Breidbach et al., 2018). Service provider's "Behavior" and "Attitude" are vital for the long term retention of the customers (Afshar et al., 2019).

Social media holds great potential for brands to come closer to the customers and further increase revenue, reduce cost, and improve efficiencies (Baird and Parasnis, 2011). Gavval and Ravi (2020) have mentioned that social media has become consumer preference to express thoughts and complaints with regards to their product and service experiences while Tripathi (2019) has emphasized that social 
media help the brands to reach to the new customers. Users are rapidly turning to social media to request and receive customer service (Xu et al., 2017). Social media helps in generating pro-consumer experiences (Dwivedi et al., 2019) and works as a forum for companies to manage their social relationships with customers (Hidayanti et al., 2018). Unlike traditional media channels, social media equips, enables, empowers \& engages its user (Bhattacharyya and Roy, 2016). The growth of digital platforms like Facebook, Twitter, Instagram, and others has attracted many brands and marketers to include them as part of their marketing mix. These channels help marketers to connect with buyers/ consumers and to interact with them. In an organization service requests made by customers, who adopted online medium to raise their concerns, have outnumbered customers, who use offline mode (Maecker et al., 2016). According to Wakefield and Wakefield (2018) poor brand experience leads to negative eWOM.

Like other social networking platforms, Twitter has witnessed multi-fold growth. The large set of data on Twitter is a vital source of information that carries user sentiment and opinions on various topics ( $\mathrm{Hu}$ et al., 2013).Retweets are considered to be the highest indicator of engagement (Leek et al., 2019).

Launched in 2006, Twitter enables its users to post/send brief messages called "Tweets". character limitation for a single Tweet was previously 140 but in the year 2017, it was doubled to 280 characters (Rosen and Ihara, 2017). Here users follow other users' "Handles" (or profiles), "Retweet" (Share the Tweets of other users), "Like" a Tweet, and can "Comment / Reply" on a Tweet. Tweets and retweets are considered to be the online equivalent of word-of-mouth (WOM) communications (Gruen et al., 2006)

In a span of around 13 years Twitter has seen some great adaptations in terms of the number of users, usability, and growth (Bary, 2020) and as a result, had drawn attention from the research community to explore more insights about this platform. A few years back researchers have even studied the nature of this platform i.e. whether it's a Social Network or a News Media (Kwak et al., 2010). Today,
Twitter is not just used by individuals but also by Governments, Policy Makers, Influencers, Celebrities, Artists, Sportspersons, Businesses, Social Organizations, Think Tanks, Armed Forces, and many other institutional level users. Owing to the profile of its users, Twitter is considered more serious compared to other networking platforms hence lands authenticity and validity if Tweet originates from reliable Handles. In 2013, a fake Tweet from the official Handle of US-based News Agency Associated Press (AP) that claimed injuries to President Obama in an alleged explosion in the White House had caused the dropping of Dow Jones Industrial Average by 143.5 points and Standard and Poor's 500 Index lost more than $\$ 136$ billion.

Twitter has registered 11.7 million mobile app downloads on the App Store in the first quarter of 2019 with 330 million monthly active users. Around 500 million Tweets are sent each day and users spent 3.39 minutes on an average each day. The majority of B2B businesses (approximately 67\%) are already using Twitter as a digital marketing tool while $75 \%$ of B2B businesses market on Twitter (Lin, 2020). $85 \%$ of Small and Medium Business (SMB) Twitter users say providing customer service on the platform is important.

Despite Twitter possessing great potential for active customer service management, several organizations in India including Banks are still employing traditional methods to handle customer grievances / concerns. These traditional methods sometimes result in customer dissatisfaction as their concerns are overlooked by the Banks thus forcing them to post negative comments on social media platforms. Hence, it was observed to figure out the kind of information customers share about the Banks and their reaction on social media w.r.t. grievances/concerns. This will portray their behavior on any of the social networking sites.

Considering the dearth of literature on customer service management by Banks through Twitter the following research questions need attention.

RQ1: What is the numbers and sentiments of Tweets that have been posted for each Bank and which sentiment type has drawn more user engagement? 
RQ2: What is the flow of positive and negative Tweets daily and the top three positive and negative terms used for each Bank?

RQ3: What is the user behavior for negative Tweets for the Banks and timings for overall Tweets and negative Tweets?

To address the said research questions, the following objectives have been framed which then have been tested empirically. The process has been explained in the latter part of the study.

RO1: To identify the volume of Tweets for each bank and their sentiment type.

RO2: To identify the significance of sentiment type on the user engagement

RO3: To identify the spill of positive and negative Tweets daily.

RO4: To identify three positive and negative terms mostly used for each Bank.on user Tweets

RO5: To identify the pattern of users' negative Tweets for the Banks.

RO6: To identify patten of Tweet Timings

The remaining study is structured as follows. In Section 2, an extensive review of the literature has been discussed. Section 3 focuses on the methodology adopted for the study. Section 4 portrays the findings and provides a detailed interpretation of the same. The last section concludes the study by discussing the theoretical contribution, managerial implications, and limitations of the study followed by highlighting the directions for future research.

\section{LITERATURE REVIEW}

\section{Customer Service}

Goofin and Price (1996) have urged that customer service is significant because it helps in boosting product quality, gaining competitive advantage and profits thus increasing overall sales and income. A study by Mishra (2007) has underlined that customer satisfaction is an asset for organizations that can further help in building a sustainable long-term relationship with the customers. In a study related to the hospitality Industry, Parasuraman et al., (1991) have talked about customer expectations of service and highlighted that customer desires for more personalized and closer relationships with the service providers. Service responsiveness is an important quality indicator of customer satisfaction (Felix, 2017).

\section{Customer Service Management in Banks}

Service quality is related to higher revenues and customer retention (Bennett and Higgins, 1988), and Banks should use service quality to beat the market competition. Chaoprasert and Elsey (2004) have argued that Banks should use service quality to beat the market competition. Another study has highlighted that Bank marketers should aim for customer satisfaction. Uppal (2010) has studied the nature, extent, and mitigation of customer complaints in Banks where the emphasis was given on the need for dedicated customer care departments along with new methods and strategies to address customer complaints. Bhaskar (2004) in his study has concluded that customer service is the foundation for business expansion and the survival of Banking business is dependent on customer service. Customer service should not be a proactive exercise and Bank marketers should focus on answering customer questions proactively to ensure pleasant banking experience (Paul et al., 2016). Efficient customer service management positively impacts customer choice for Bank (Kochukalam et al., 2018).

\section{Twitter as a Social Networking Platform}

Growth in adoption and usage of Twitter by different segments of users has attracted eyeballs from many Researchers and Academicians. Many scholarly works have been done in the past to uncover the use of Twitter in a different scenario. A few prominent studies are mentioned below.

By analyzing users' sentiments on Twitter for a service, areas of customer satisfaction/ dissatisfaction can be identified (Misopoulos et al., 2014). The dual nature of Twitter as a one-to-one and one-to-many communication channel can be leveraged efficiently to promote the business as well as to address customer complaints where the main business or corporate account can be used for brand promotion / strategic announcements while a secondary account can be used to address customer grievances (Burton and Soboleva, 2011). A study titled "Twitter Power: Tweets as Electronic Word of Mouth" (Jansen et al., 2009) has revealed that Twitter can be used to build a brand relationship with the customers 
and as a competitive intelligence platform. The real-time character of Twitter differentiates it from other social networking platforms and hence can be used for the on-time tracking of natural hazards like an earthquake (Sakaki et al., 2010). Kwak et al (2010) in their study has called Twitter an information-sharing platform instead of a social networking platform. Organizations can improve customer relationships by listening to and addressing specific customer complaints on Twitter (Ma et al/, 2015). The User Generated Content (UGC) on Twitter holds immense business value (Liu et al., 2017). Alwagait and Shahzad (2014) in their study experimented and concluded that timings play an important role in the impact of the Tweets. Ahsan et al. (2019) have argued that due to fast and broad delivery of Tweets as well as the absence of any content pre-check mechanism, Twitter has also been used to spread false information as well as rumors to create favorable sentiments, hence it is essential to devise methods to timely detect the tweets.

\section{Sentiment Analysis on Twitter}

According to a research study done by Thelwall et al., (2011), the objective of sentiment analysis/opinion mining is to predict the behavior of the users, to evaluate the impact of big events, to discover a trend/pattern and to track public opinion on various issues. Twitter can be considered an ideal platform for sentiment analysis as it provides information on users' behavior w.r.t their opinions and experiences hence reveals a lot of insights about users' sentiments (positive, neutral, or negative) for a topic. According to Pak and Paroubek (2010), microblogging sites like Twitter is a rich source of data for sentiment analysis/opinion mining due to their diversified user base. Savage (2011) has observed that Tweets at the individual level might not provide deep insights but collectively they can mirror the opinion of a larger group. Stock market mood prediction (Bollen et al., 2011), Predicting Elections through Twitter (Tumasjan et al., 2010) are notable work done in Twitter sentiment analysis amongst others.

\section{Twitter as a Customer Service Management Platform}

To register complaints, social media channels are quite relevant as they allow wide exposure to it and rapid escalation (Stauss and Seidel,
2019). The outcome of a survey done by Twitter in the UK has revealed that $61 \%$ of people admitted that the public nature of the platform makes it an ideal place to talk about service queries with the brands (Picazo, 2016). Businesses can draw benefits through Twitter by interacting with their audiences (Taecharungroj, 2017).

The popularity of Twitter among businesses is just not restricted to the promotion of products and services but also as a service platform to address customer issues by interacting with them on a real-time basis. In 2009, American Consumer Electronic Retailer BestBuy Co instituted Twelpforce (@twelpforce) a team of 3,000 employees to respond to customer queries and to address complaints on Twitter (Wauters, 2009) which was later transformed into a dedicated online community. Huang (2015) has highlighted that every month millions of interactions related to customer service are happening on Twitter. Several Twitter advertisers have mentioned that around $80 \%$ of total customer service requests come through Twitter.

Cairns (2016) in his blog post on Twitter has mentioned that when airline customers register complaints on Twitter and customers receives timely response; they're willing to pay on an average $\$ 9$ more for their next purchase from that airline". Twitter as a platform also empowers businesses to manage their customer service using a series of customer service-based features like Displaying support hours so the complainants know when they can expect a response, Direct Messaging or DM, this feature is to handle complex issues or exchange of sensitive information privately, Call to Action (CTA) button on Tweets which allows the customer to send a direct message to the business, Welcome Message to initiate a friendly conversation (Alton, n.d.)

Companies that invest in customer service on Twitter have managed to resolve issues on one-sixth cost as compared to that of the call centers with a $95 \%$ resolution rate and $90 \%$ customer satisfaction rate (Masri et al., 2015). Several organizations have embraced Twitter as one of the efficient channels to communicate with customers and other stakeholders (Malhotra and Malhotra, 2016). 
From a Bank marketing perspective, customer behavior analysis on Twitter can provide information on customer grievances, concerns, and other issues which can help Bank marketers to improve the service quality. This study is based on Five Indian Private Commercial Banks (Foreign Private Banks operating in India has been excluded). These Banks are, HDFC Bank ("HDFC") which was incorporated in August 1994. Forbes magazine has ranked HDFC at the top of its first-ever list of India's Best Banks 2019 on customer service and technological advancement. ICICI Bank ("ICICI") has formally started its Banking operations in 1998. ICICI was the 1st Bank in India and amongst few global Banks to launch a service allowing cross-border remittances over social media. On the customer service front, ICICI Bank was the 1st Indian Bank to launch a dedicated customer service Twitter Handle in 2009 (@ICICI_Care). In the year
500, published in February 2014 by Banker magazine, KMB was ranked 245th among the world's top 500 Banks with a brand valuation of around half a billion dollars ( $\$ 481$ million) and a brand rating of $\mathrm{AA}+$.

\section{Theoretical Underpinning}

There are multiple theories on customer behavior and the majority of them talk about "dissatisfaction" and its determinants. But, "complaint" is the consequence of "dissatisfaction" hence the theory of Consumer Complaining Behaviour (CCB) is found to be the most relevant and is used in this study as a theoretical framework. This theory has been resorted to explaining the behavior of consumers through their Tweets. As stated by Halstead (2002) feeling of dissatisfaction triggers consumer complaint behavior, so consumer complaining behavior is one of the prominently studied phenomena.

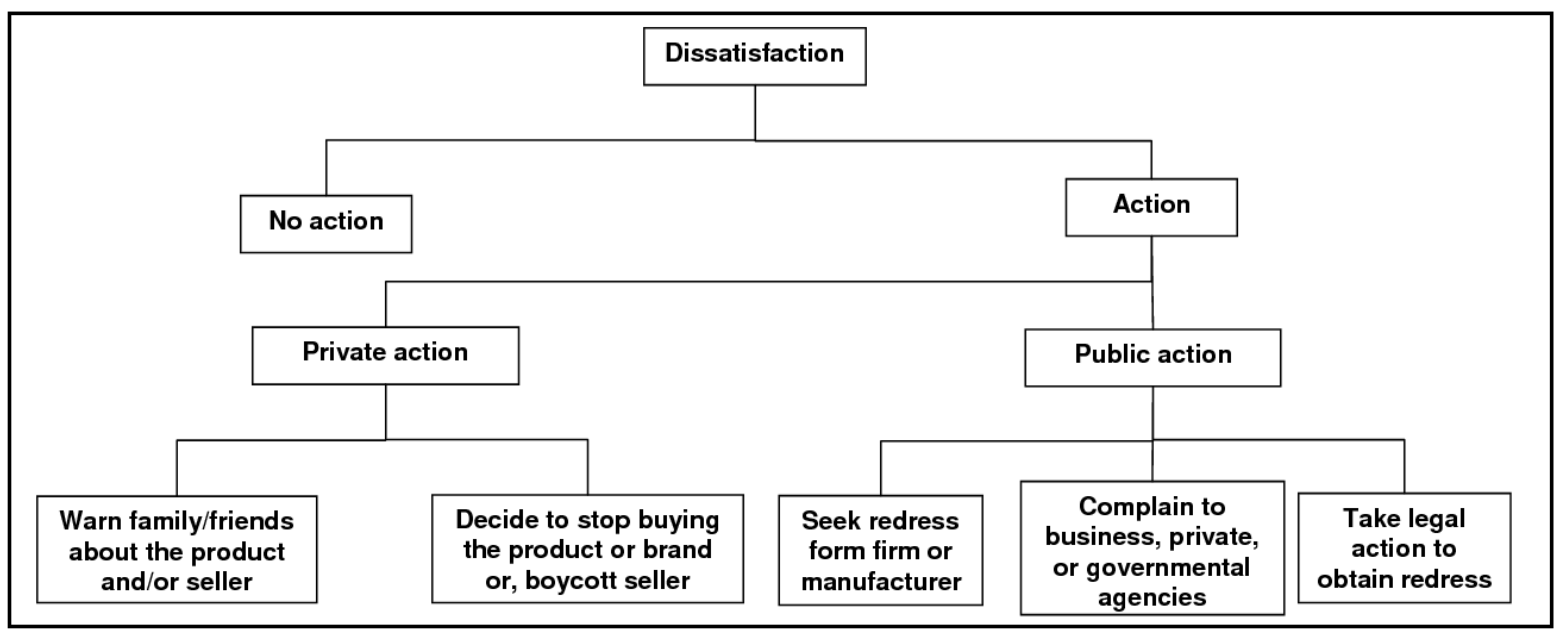

Figure 1: A Taxonomy of Consumer Complaint (Day and Landon)

2015, ICICI became the first Bank in Asia to introduce money transfer services on Twitter. It has also launched India's 1st "Social Customer Care" service in an exclusive tie-up with Twitter to offer advanced care to its customers (Chaturvedi, 2016). Third Bank in our list is Axis Bank ("AXIS") which was incorporated in the year 1993 and is one of the largest private Banks in the country in terms of total assets. Next Bank on the list is YES Bank ("YES") which began its commercial Banking operations in May 2004. In 2017, the Bank was awarded the "Bank of the Year India" award from The Banker magazine. Last Bank in the list is Kotak Mahindra Bank ("KMB"). KMB was launched in February 2003. In a study by Brand Finance Banking
Day and Landon (1977) taxonomy of consumer complaint behavior has been widely accepted theory and has been mentioned by several authors in their respective studies. In this taxonomy, consumers have been divided into two broad categories, one, those who will "take some action" and others, those who will "take no action" (refer Figure 1). Action taken can be either public (complaint to provider, third-party or legal complaint) or private (negative word of mouth, a personal boycott of provider) while "no action" is about neglecting or ignoring. The "action taking" consumer set whether public or private, constitutes the base for our study. From the perspective of this study, customer dissatisfaction occurs when service 
commitments are not fulfilled and customer initiates actions in the form of complaints.

\section{Selection of Banks}

The Five Banksthat have been considered for the study are shortlisted based on the number of followers (refer Table 1) on the Bank's official corporate Twitter Handles.Interestingly, total asset wise same set of Five Banks top the list (data assessed by business portal Moneycontrol.com through Bombay Stock Exchange as shown in Table 2).

Table 1: Number of followers for each Bank

\begin{tabular}{|c|c|c|c|}
\hline $\begin{array}{l}\text { S. } \\
\text { No }\end{array}$ & Bank Name & Following & Followers \\
\hline 1 & $\begin{array}{l}\text { State Bank of India } \\
\text { (@TheOfficialSBI) }\end{array}$ & 18 & 3959830 \\
\hline 2 & YES BANK (@YESBANK) & 92 & 1728161 \\
\hline 3 & ICICI Bank (@ICICIBank) & 3759 & 531883 \\
\hline 4 & $\begin{array}{l}\text { ReserveBankOfIndia } \\
\text { (@RBI) }\end{array}$ & 0 & 517564 \\
\hline 5 & $\begin{array}{l}\text { HDFC Bank } \\
\text { (@HDFC_Bank) }\end{array}$ & 248 & 355977 \\
\hline 6 & Axis Bank (@AxisBank) & 380 & 303701 \\
\hline 7 & $\begin{array}{l}\text { HDFC Bank Cares } \\
\text { (@HDFCBank_Cares) }\end{array}$ & 2027 & 264443 \\
\hline 8 & $\begin{array}{l}\text { ICICI Bank Cares } \\
\text { (@ICICIBank_Care) }\end{array}$ & 15873 & 247990 \\
\hline 9 & $\begin{array}{l}\text { Kotak Mahindra Bank } \\
\text { (@KotakBankLtd) }\end{array}$ & 1340 & 238947 \\
\hline
\end{tabular}

Table 2: Top Private Banks in terms of Total Asset valuation

\begin{tabular}{|l|r|}
\hline \multicolumn{2}{|c|}{ Bank - Private } \\
\hline \multicolumn{2}{|c|}{$\begin{array}{c}\text { Total Assets as per the latest Balance Sheet } \\
\text { available }\end{array}$} \\
\hline Company Name & Total Assets (Rs.cr) \\
\hline HDFC Bank & $10,58,910.81$ \\
\hline ICICI Bank & $7,64,459.23$ \\
\hline Axis Bank & $6,40,730.77$ \\
\hline Yes Bank & $3,13,950.96$ \\
\hline Kotak Mahindra & $2,67,393.46$ \\
\hline Indusind Bank & $2,38,425.26$ \\
\hline
\end{tabular}

Post literature review it has been concluded that no specific study has been done to explore the customer behavior on Twitter for Private Banks in India though researchers through multiple studies and findings have emphasized that for service organizations Twitter can provide vital information on customer behavior, priorities, and concerns

\section{RESEARCH METHODOLOGY Research Design}

This study adopted a mixed-method approach. Initially using qualitative data analysis, Tweets were identified then quantitative methods have been used to analyze the Tweets. Systematic sampling techniques have been used to extract the data from Twitter. The sampling element of the study includes the top five commercial private Banks and the Tweets for these banks were considered as a sampling unit.

\section{Study Duration}

The study is based on the public Twitter data of the Banks for 06 months' duration(21 December 2018 - 21 June 2019).

\section{Data Collection}

The historical Tweets were acquired through a Twitter application programming interface (API) in the batch size of a maximum of 20,000 Tweets per report using individual Boolean search query for each Bank. The logic behind each query was to retrieve data that is relevant to each Bank while avoiding the Tweets which are meant for sister/group companies of the Banks or meant for products not directly offered by the Banks or Tweets that are authored by the Banks themselves. Table 3 shows the Bank name and number of Tweets for each of the Bank considered for the study.

Table 3: Number of Public Tweets for each Bank. Source: Authors' Calculations

\begin{tabular}{|c|c|}
\hline ICICI & 240504 \\
\hline HDFC & 229913 \\
\hline AXIS & 103901 \\
\hline YES & 47404 \\
\hline KMB & 40728 \\
\hline
\end{tabular}

The used queries have also covered Tweets where Banks name, hashtag, or official Twitter Handles were mentioned/tagged. Basis the Boolean queries used for each of the Bank; the number of Bank's public Tweets data with multiple columns (shown in Table 4) has been assessed in the volume. 
Table 4: Columns on the report and their explanation

\begin{tabular}{|c|c|c|}
\hline $\begin{array}{l}\text { S. } \\
\text { No }\end{array}$ & $\begin{array}{l}\text { Column } \\
\text { Name }\end{array}$ & $\begin{array}{l}\text { Explanation / Value on } \\
\text { the Report }\end{array}$ \\
\hline 1 & $\begin{array}{l}\text { Date and } \\
\text { Time }\end{array}$ & Date and Time of Tweet \\
\hline 2 & Headline & Blank \\
\hline 3 & URL & Tweet Public URL \\
\hline 4 & $\begin{array}{l}\text { Opening } \\
\text { Text }\end{array}$ & Blank \\
\hline 5 & $\begin{array}{l}\text { Hit } \\
\text { Sentence }\end{array}$ & Tweet (Content) \\
\hline 6 & Source & Platform (Twitter) \\
\hline 7 & Influencer & Tweet Author Handle \\
\hline 8 & Country & $\begin{array}{l}\text { Country of Origin of the } \\
\text { Tweet }\end{array}$ \\
\hline 9 & Sub-region & Blank \\
\hline 10 & Language & Language used in Tweet \\
\hline 11 & Reach & $\begin{array}{l}\text { Number of Followers of } \\
\text { the Tweet Author on } \\
\text { Twitter. This value is } \\
\text { dynamic in nature }\end{array}$ \\
\hline 12 & $\begin{array}{l}\text { Twitter } \\
\text { Social Echo }\end{array}$ & Blank \\
\hline 13 & $\begin{array}{l}\text { Facebook } \\
\text { Social Echo }\end{array}$ & Blank \\
\hline 14 & $\begin{array}{l}\text { National } \\
\text { Viewership }\end{array}$ & $\mathrm{O}($ Zero $)$ \\
\hline 15 & Engagement & $\begin{array}{l}\text { A dynamic numeric value } \\
\text { representing summation } \\
\text { of Replies, Retweets and } \\
\text { Likes; received on a } \\
\text { particularTweet }\end{array}$ \\
\hline 16 & AVE & 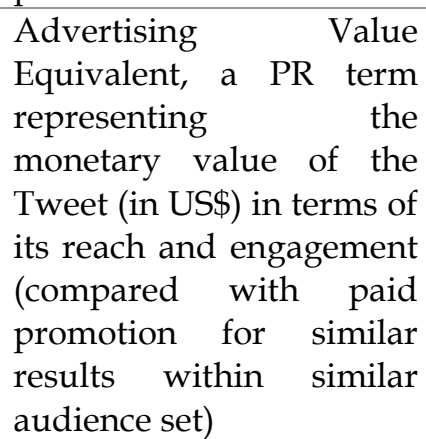 \\
\hline 17 & Sentiment & $\begin{array}{l}\text { Tome of the Tweet - } \\
\text { Positive, Neutral or } \\
\text { Negative }\end{array}$ \\
\hline 18 & Key Phrases & $\begin{array}{l}\text { Terms mentioned on the } \\
\text { Tweet }\end{array}$ \\
\hline 19 & Input Name & Report Name \\
\hline 20 & Keywords & $\begin{array}{l}\text { Search Terms mentioned } \\
\text { on the Tweet as per } \\
\text { Boolean query used }\end{array}$ \\
\hline 21 & $\begin{array}{l}\text { Document } \\
\text { Tags }\end{array}$ & Blank \\
\hline
\end{tabular}

\section{Data Relevancy}

For relevancy, only Tweets posted in the English Language from India have been considered. Also, some of the irrelevant columns were deleted from the report and columns (as shown below in Table 5) have been considered for further analysis.

Table 5: Columns considered for analysis

\begin{tabular}{|c|c|}
\hline S. No & Column \\
\hline $\mathbf{1}$ & Date \\
\hline $\mathbf{2}$ & Time \\
\hline $\mathbf{3}$ & URL \\
\hline $\mathbf{4}$ & Hit Sentence \\
\hline $\mathbf{5}$ & Reach \\
\hline $\mathbf{6}$ & Engagement \\
\hline $\mathbf{7}$ & Sentiment \\
\hline $\mathbf{8}$ & Keywords \\
\hline
\end{tabular}

\section{Data Cleaning}

As part of the data cleaning process, Tweets with "BLANK" engagement were also omitted Final data number post relevancy checksand cleaning for each Bank is shown below in Table 6.

Table 6: Number of Tweets for each Bank after data cleaning.Source: Authors' Calculations

\begin{tabular}{|c|l|}
\hline ICICI & 197088 \\
\hline HDFC & 179425 \\
\hline AXIS & 62258 \\
\hline YES & 39400 \\
\hline KMB & 32649 \\
\hline
\end{tabular}

To use sentiment analysis as a tool for research to gauge the sentiments contained in the Tweet, certain data processing is to be carried out after the first step of data cleaning been already done as mentioned above. First, the stopwords (such as in, an, is the, of, etc.), the words that are not relevant in conducting lexicon-based sentiment analysis were removed from the text data of the Tweets. Next, the top words, in terms of the frequency, were generated for each of the Banks over the entire duration of the data timeline used in this research. Further, it was also found out that what are the words that contributed most to the negative sentiment, and the words that contributed most to the positive sentiment. A time series plot was also generated for the negative sentiments and positive sentiments, for all the Banks for the entire data timeline. TTest for Two-Sample Assuming Unequal Variance was used to find if any significant 
difference was done for all the Banks combined to get a holistic view followed by each Bank individually. The value of alpha has been considered as 0.05 and the null hypothesis was set as 0 (two-tailed test) i.e. there is no significant difference between the mean of two data series.

\section{RESULTS AND DISCUSSION}

Numbers and sentiments of Tweets posted for each Bank and sentiment type with higher user engagement

Based on the analysis, the following results have been obtained (refer Table 7) with shows the number of Tweets and their sentiment type for the five banks that have been considered.

The above data shows that overall, the Five Banks have received more Tweets with "Neutral" tone or sentiment followed by negative and positive Tweets respectively. At the Bank level, ICICI has received the highest number of overall Tweets while KMB is at the lowest end but at the same time, $\mathrm{KMB}$ has received the highest \% of Tweets with negative tone among all the 05 Banks. YES is the recipient of the highest $\%$ of positive
Tweets.

To identify sentiment type that draws more user engagement,T-Test for Two-Sample Assuming Unequal Variance is used considering Tweets with positive and negative sentiments. First, the test is done for all the Banks combined to get a holistic view followed by each Bank individually. The value of alpha is considered as 0.05 and null hypothesis as 0 i.e. there is no significant difference between the mean of two data series.

For all the Banks combined, the output Pvalue is minutely smaller i.e. 0.049 than stated mentioned P-value of 0.05 which rejects the null hypothesis that there is no significant difference between the mean of positive and negative Tweets (as shown on above Table 8). Further mean value of the engagement of negative Tweets is 1.722 while for positive Tweets it is 1.443 . This shows that negative Tweets carry more user engagement than positive ones.

AXIS

0.009 than the mentioned P-value of 0.05 which

Table 7: Number of Tweets and their sentiment type for each Bank. Source: Authors' Calculations

\begin{tabular}{|l|l|l|l|l|l|l|l|}
\hline Bank & $\begin{array}{l}\text { Total } \\
\text { Tweets }\end{array}$ & $\begin{array}{l}\text { Positive } \\
\text { Tweets }\end{array}$ & $\begin{array}{c}\text { \% Share of } \\
\text { Positive } \\
\text { Tweets on } \\
\text { Total Tweets }\end{array}$ & $\begin{array}{l}\text { Neutral } \\
\text { Tweets }\end{array}$ & $\begin{array}{c}\text { \% Share of } \\
\text { Neutral } \\
\text { Tweets on } \\
\text { Total Tweets }\end{array}$ & $\begin{array}{c}\text { Negative } \\
\text { Tweets }\end{array}$ & $\begin{array}{c}\text { \% Share of } \\
\text { Negative } \\
\text { Tweets on } \\
\text { Total Tweets }\end{array}$ \\
\hline ICICI & 197088 & 44065 & 22.35 & 88498 & 44.90 & 64525 & 32.73 \\
\hline HDFC & 179425 & 35775 & 19.93 & 86064 & 47.96 & 57585 & 32.09 \\
\hline AXIS & 62258 & 13265 & 21.30 & 27290 & 43.83 & 21703 & 34.85 \\
\hline KMB & 32649 & 7602 & 23.28 & 12798 & 39.19 & 12249 & 37.51 \\
\hline YES & 39400 & 10069 & 25.55 & 19239 & 48.82 & 10092 & 25.61 \\
\hline Total & 510820 & 110776 & 21.68 & 233889 & 45.78 & 166154 & 32.52 \\
\hline
\end{tabular}

Table 8: t-test Result- All Banks Combined.

\begin{tabular}{|lrr|}
\hline \multicolumn{3}{|c|}{$t$-Test: Two-Sample Assuming Unequal Variances } \\
\hline \multicolumn{3}{|c|}{ All Banks } \\
\hline Mean & Positive Sentiment & Negative Sentiment \\
Variance & 1.443863688 & 1.722588683 \\
Observations & 1096.418805 & 1651271 \\
Hypothesized Mean Difference & 110775 & \\
Df & 0 & \\
t Stat & 267247 & \\
P(T<=t) one-tail & -1.967624898 & \\
t Critical one-tail & 0.024556123 & \\
P(T<=t) two-tail & 1.644859329 & \\
t Critical two-tail & 0.049112245 & \\
\hline
\end{tabular}

Source: Authors' Calculations 
rejects the null hypothesis. For AXIS, the mean of the Tweets with positive sentiments is 2.220 while 1.459 for negative Tweets which indicates higher user engagement for positive Tweets (refer Table 9).

\section{HDFC}

As shown in Table 10, the value of output Pvalue is higher than the mentioned $\mathrm{P}$-value of 0.05 which does not reject the null hypothesis that is no significant difference between the mean of two sentiments.

\section{ICICI}

The value of output P-value is smaller i.e. 0.007 than the mentioned P-value of 0.05 which rejects the null hypothesis (shown in Table 11). For ICICI, Tweets with negative sentiments have a mean value of 2.004 and 1.200 for positive Tweets which highlights higher engagement for negative Tweets.

Table 9: t-test Result: AXIS. Source: Authors' Calculations

(t-Test: Two-Sample Assuming Unequal Variances)

\begin{tabular}{|l|r|r|}
\hline \multicolumn{3}{|c|}{ AXIS } \\
\hline Mean & Positive Sentiment & Negative Sentiment \\
\hline Variance & 2.220429702 & 1.459521725 \\
\hline Observations & 958.1290307 & 318.201004 \\
\hline Hypothesized Mean Difference & 13265 & 21703 \\
\hline Df & 0 & \\
\hline$t$ Stat & 18724 & \\
\hline $\mathrm{P}(\mathrm{T}<=\mathrm{t})$ one-tail & 2.581330228 & \\
\hline $\mathrm{t}$ Critical one-tail & 0.004924785 & \\
\hline $\mathrm{P}(\mathrm{T}<=\mathrm{t})$ two-tail & 1.644935012 & \\
\hline $\mathrm{t}$ Critical two-tail & 0.00984957 & \\
\hline
\end{tabular}

Table 10: t-test Result: HDFC. Source: Authors' Calculations

\begin{tabular}{|l|r|r|}
\hline & \multicolumn{1}{|c|}{ HDFC } & \multicolumn{1}{|c|}{ Negative Sentiment } \\
\hline Mean & 1.453737351 & 1.495528349 \\
\hline Variance & 1196.958291 & 525.0756651 \\
\hline Observations & 35774 & 57585 \\
\hline Hypothesized Mean Difference & 0 & \\
\hline Df & 55373 & \\
\hline $\mathrm{t}$ Stat & -0.202532348 & \\
\hline $\mathrm{P}(\mathrm{T}<=\mathrm{t})$ one-tail & 0.419750658 & \\
\hline $\mathrm{t}$ Critical one-tail & 1.644881146 & \\
\hline $\mathrm{P}(\mathrm{T}<=\mathrm{t})$ two-tail & 0.839501316 & \\
\hline $\mathrm{t}$ Critical two-tail & 1.960006827 & \\
\hline
\end{tabular}

Table 11: t-test Result: ICICI. Source: Authors' Calculations

\begin{tabular}{|l|r|r|}
\hline \multicolumn{3}{|c|}{ ICICI } \\
\hline & Positive Sentiment & Negative Sentiment \\
\hline Mean & 1.200186093 & 2.004478954 \\
\hline Variance & 1417.714299 & 3720.623618 \\
\hline Observations & 44064 & 64524 \\
\hline Hypothesized Mean Difference & 0 & \\
\hline Df & 107573 & \\
\hline $\mathrm{t}$ Stat & -2.683413069 & \\
\hline $\mathrm{P}(\mathrm{T}<=\mathrm{t})$ one-tail & 0.003644303 & \\
\hline $\mathrm{t}$ Critical one-tail & 1.644867792 & \\
\hline $\mathrm{P}(\mathrm{T}<=\mathrm{t}) \mathrm{two}-$ tail & 0.007288606 & \\
\hline $\mathrm{t}$ Critical two-tail & 1.959986037 & \\
\hline
\end{tabular}


KMB

Table 12 shows that the value of output Pvalue is higher than the mentioned P-value of 0.05 which does not reject the null hypothesis that is no significant difference between the mean of two sentiments of Tweets (1.141 for positive and 1.123 for negative).

YES

The value of output P-value is smaller i.e 0.0001 than the mentioned P-value of 0.05 which rejects the null hypothesis (as shown in Table 13). For YES, the mean of Tweets with negative sentiments is 2.508 which is much higher than that of the mean of positive Tweets i.e. 1.680. Hence, for this bank negative Tweets possess larger engagement value than Tweets having positive sentiments.

Flow of positive and negative Tweets on a day basis and top 10 terms used for each Bank along with the popular positive and negative terms

To see the trend of positive and negative time series graph for Tweets with negative (refer figure 2) and positive sentiments (refer figure

Table 12: t-test Result: KMB. Source: Authors' Calculations

(t-Test: Two-Sample Assuming Unequal Variances)

\begin{tabular}{|l|r|r|}
\hline \multicolumn{2}{|c|}{ KMB } & Negative Sentiment \\
\hline & Positive Sentiment & 1.123856956 \\
\hline Mean & 1.141034074 & 56.70295656 \\
\hline Variance & 182.2003699 & 12248 \\
\hline Observations & 7601 & \\
\hline Dypothesized Mean Difference & 10574 & \\
\hline$t$ Stat & 0.101570167 & \\
\hline P $(T<=t)$ one-tail & 0.459549893 & \\
\hline$t$ Critical one-tail & 1.644997745 & \\
\hline$P(T<=t)$ two-tail & 0.919099786 & \\
\hline$t$ Critical two-tail & 1.960188359 & \\
\hline
\end{tabular}

Table 13: t-test Result: YES. Source: Authors' Calculations

\begin{tabular}{|l|r|r|}
\hline \multicolumn{3}{|c|}{ YES } \\
\hline & Positive Sentiment & Negative Sentiment \\
\hline Mean & 1.680870083 & 2.508571995 \\
\hline Variance & 204.8208638 & 277.6999017 \\
\hline Observations & 10068 & 10091 \\
\hline Hypothesized Mean Difference & 0 & \\
\hline Df & 19720 & \\
\hline $\mathrm{t}$ Stat & -3.783315754 & \\
\hline $\mathrm{P}(\mathrm{T}<=\mathrm{t})$ one-tail & $7.76051 \mathrm{E}-05$ & \\
\hline $\mathrm{t}$ Critical one-tail & 1.644930901 & \\
\hline $\mathrm{P}(\mathrm{T}<=\mathrm{t})$ two-tail & 0.00015521 & \\
\hline $\mathrm{t}$ Critical two-tail & 1.96008429 & \\
\hline
\end{tabular}

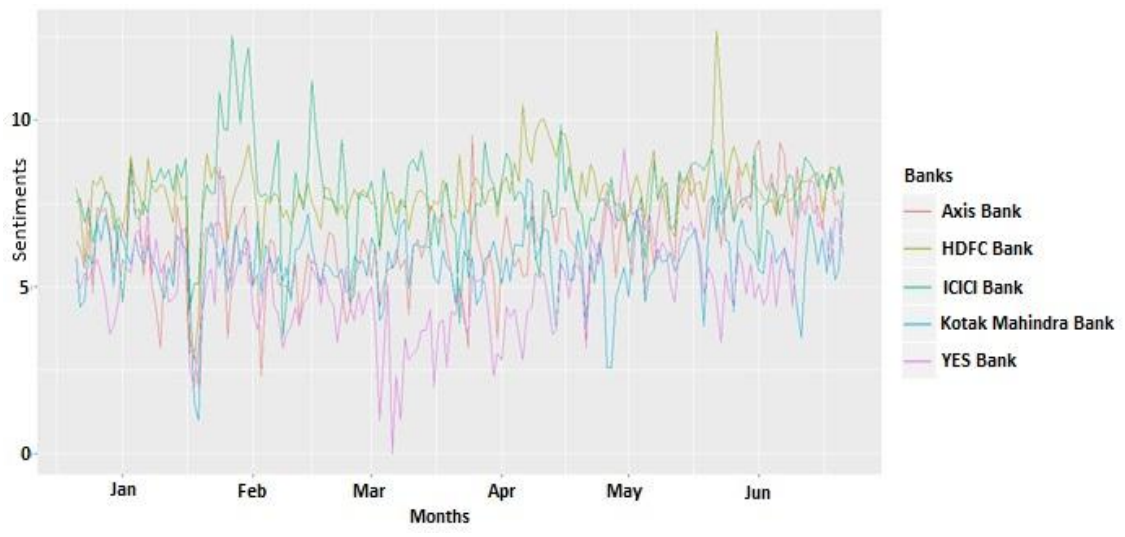

Figure 2: Flow of Negative Tweets 


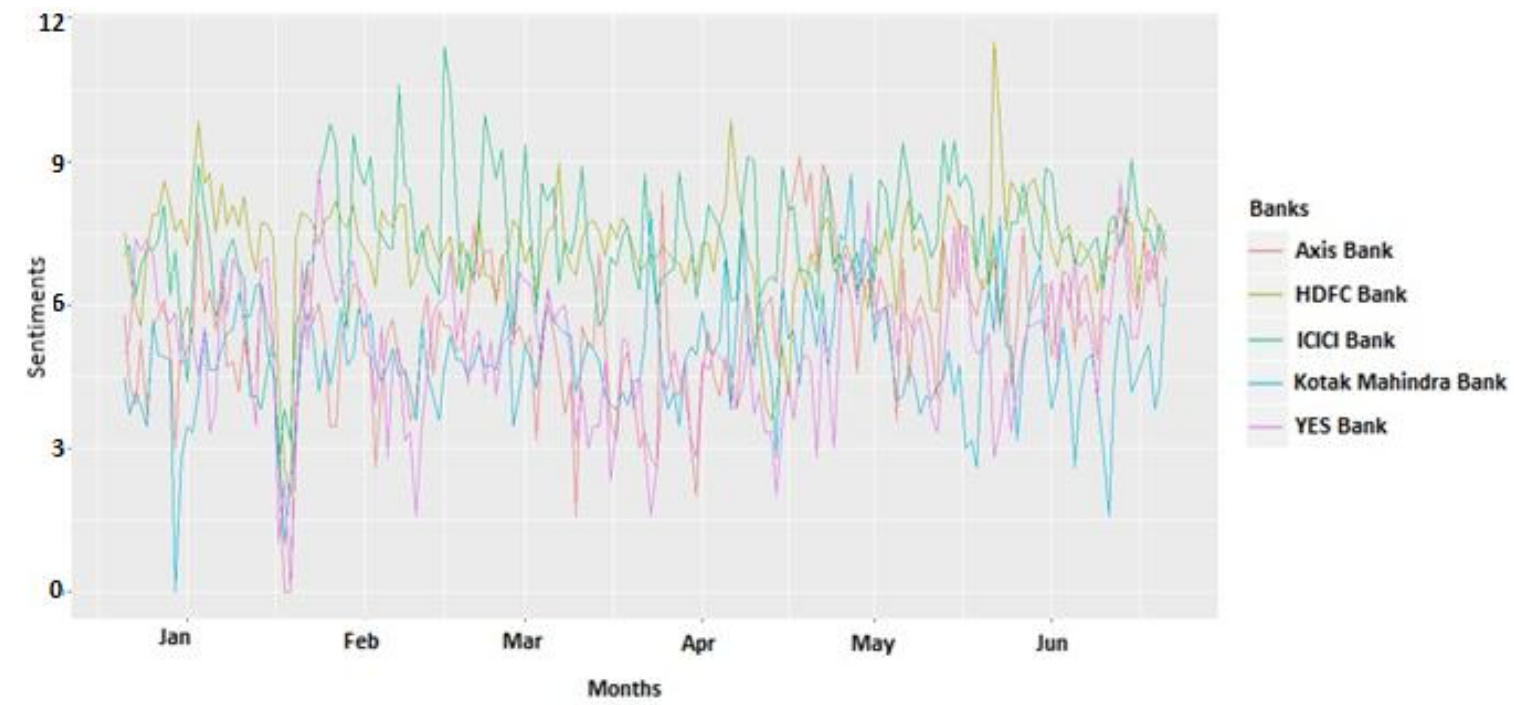

Figure 3: Flow of Positive Tweets

3) has been generated respectively.

This shows that a large number of negative Tweets for ICICI at the end of January 2019 came amid termination of its CEO (Mukherjee, 2019) while another spike was seen around mid-February when users started complaining against one of its employees (Telanganatoday, 2019). Rise in negative Tweets for HDFC in June 2019 is probably since HDFC Mutual Fund declared investing in the NonConvertible Debentures (NCDs) of cash strapped Essel Group (Borate, 2019). Figure 5 shows the flow of positive Tweets for the Banks. The trend of the tweets shows the spike on positive Tweets for ICICI in February which came after a celebrity featured product ad got high user engagement.For HDFC, rise in positive Tweets came after the news about the Banks'decision to support the restoration of 20 cyclone-affected schools in the state of Odisha (Pande, 2019)

Identification of the Top 03 positive and negative terms used for each Bank

\section{AXIS}

The analysis of the Tweet has revealed that for AXIS the top three negative terms are "atrocity", "conspiracy" and "problem" while "support", "refund" and "work" are the top three positive terms used frequently for the Bank.

A similar analysis for the other four banks has also been done. For HDFC "harassment", 'issue' and "compliant" are the frequently used negative terms whereas "good",

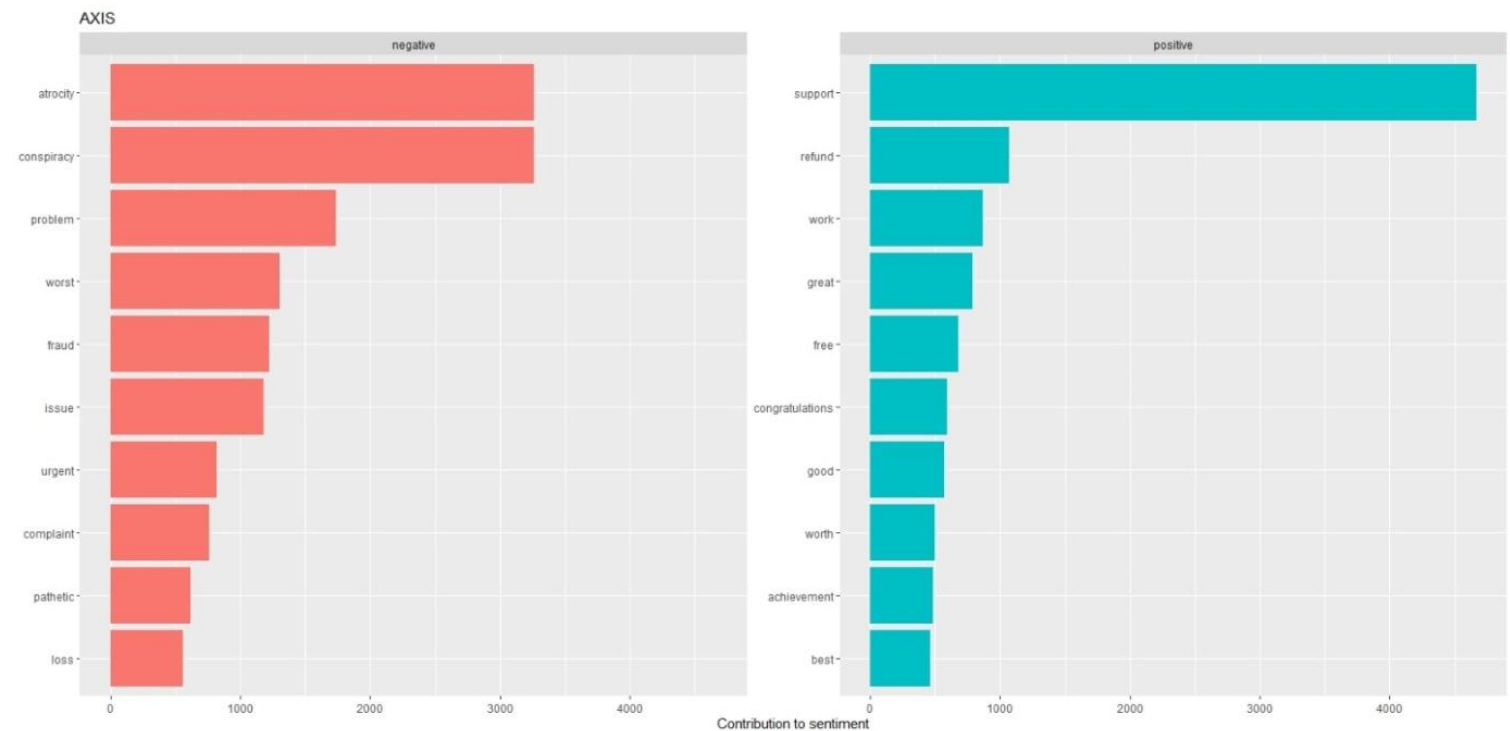

Figure 4: Popular positive and negative terms for AXIS 
"cashback" and "support" are the top negative terms used. In the case of ICICI, frequently negative terms used are "fraud", "cheating" and "scam" while positive terms "free", "benefits" and "support" are mostly used terms "worst", "issue" and "fraud" are mostly used for KMB on negative Tweets while on the positive graph "successful", "prosperous" and "contribution" are the top terms mentioned by its users. Lastly, for YES, top three negative terms used on the Tweets are "loss", "bad" and "issue" while "great", "good" and "support" are the top positive terms.

\subsection{Description of user behaviour for negative Tweets for the Banks and timings for overall and negative Tweets}

Tweets with negative sentiments have been analyzed to evaluate the Tweeting pattern (refer below Table 14).
Based on the analysis as shown in Table 14, it has been concluded that, On KMB Tweets, 5391 Tweets have been marked to Bank Chairman Uday Kotak along with other Handles while in 3168 Tweets $(25.86 \%$ of total negative Tweets) only the Chairman has been marked. YES doesn't have dedicated Handle for customer support and encourage its customers to register complaints via emails. HDFC has dedicated official Handles for Home Loan New Customers, Home Loan Current Customer support, Education Loan customers, and Bank News. 2597 Tweets contain the mention of Home Loan New Customers and Home Loan Current Customer support Handles, 1454 have also mentioned Bank News Handle and 78 Tweets contain Education loan Handle mention. For YES 65\% Tweets while for ICICI 51.84\% Tweets haven't been marked to any of the Bank Twitter Handle (contains the name of the respective Bank only).

Table 14: Pattern of Grievance Tweeting. Source: Authors' Calculations

\begin{tabular}{|c|c|c|c|c|c|}
\hline \multirow{7}{*}{ Bank } & \multirow{7}{*}{$\begin{array}{l}\text { Total } \\
\text { number of } \\
\text { Negative } \\
\text { Tweets }\end{array}$} & \multicolumn{4}{|c|}{ Number of Tweets marked as below } \\
\hline & & Only to Support & Support & Only & Handle \\
\hline & & Handle and its \% & Handle & Corporate & Tagged \\
\hline & & contribution on & Corporate & Handle and its \% & Bank Name or \\
\hline & & negative & Handle + other & contribution on & Hashtag \\
\hline & & Tweets & Handles and its & negative & mentioned) and its \\
\hline & & & $\begin{array}{lr}\% & \text { contribution } \\
\text { on } & \text { total } \\
\text { negative Tweets }\end{array}$ & Tweet & $\begin{array}{l}\% \text { contribution on } \\
\text { total negative } \\
\text { Tweets }\end{array}$ \\
\hline ICICI & 64525 & $9056-14.03 \%$ & $9162-14.19 \%$ & $12855-19.92 \%$ & $33452-51.84 \%$ \\
\hline HDFC & 57585 & $30317-52.64 \%$ & $4277-7.42 \%$ & $197-0.34 \%$ & $22794-39.58 \%$ \\
\hline AXIS & 21703 & $5378-24.77 \%$ & $7984-36.78 \%$ & $4174-19.23 \%$ & $4167-19.20 \%$ \\
\hline KMB & 12249 & $995-8.12 \%$ & $6363-51.94 \%$ & $4568-37.29 \%$ & $323-2.63 \%$ \\
\hline YES & 10092 & --------- & ------- & $3532-34.99 \%$ & $6560-65 \%$ \\
\hline
\end{tabular}

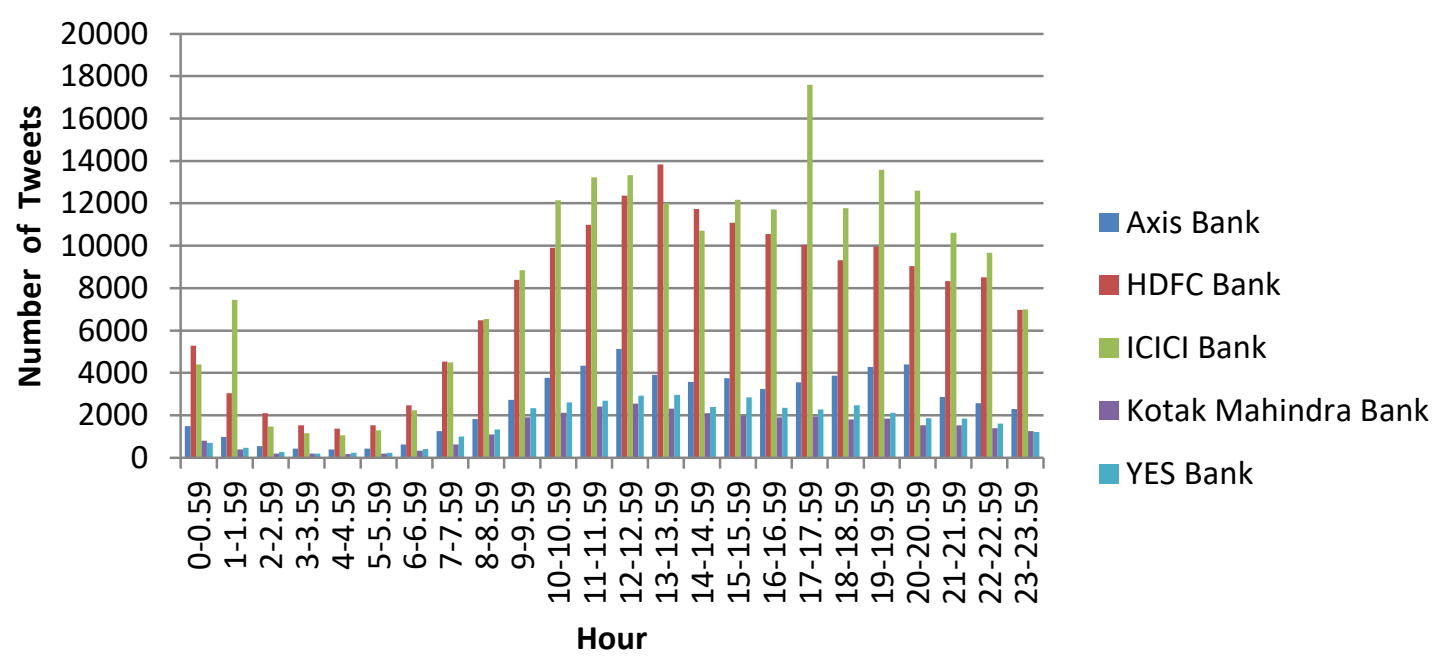

Figure 5: Hour wise overall Tweets for all the Banks combined 
Further graphical representation of the number of overall Tweets and negative Tweets per hour, has been done for all the Banks combined and then for the individual Banks to find out the pattern of Tweets timings.

Figure 5 reveals that ICICI has received the highest number of overall Tweets between 17.00 - 17.59 hours while the period 11.0011.59 is the peak negative hour for the Bank (Figure 6). For HDFC $13.00-13.59$ is the peak hour in terms of overall as well as negative Tweets

It has been observed (Figure 7 and Figure 8) that 12.00-12.59 is the peak hour for AXIS for overall as well as negative Tweets while 20.0020.59 and 19.00-19.59 are at 2nd and 3rd positions in terms of receiving the highest number of overall Tweets. Hour 11.00-11.59 is in the 2nd position for receiving the highest number of negative Tweets.

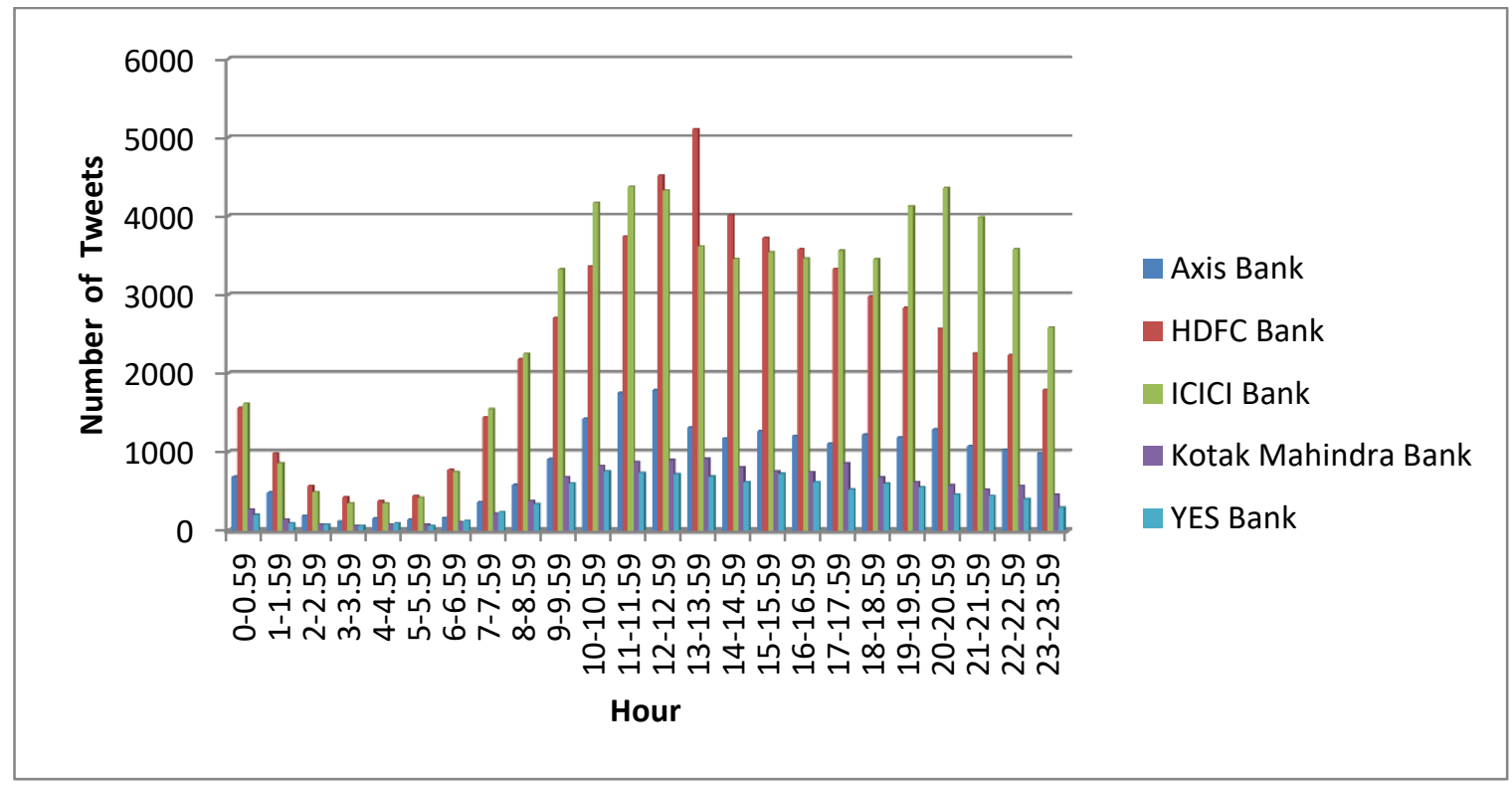

Figure 6: Hour wise negative Tweets for all the Banks combined

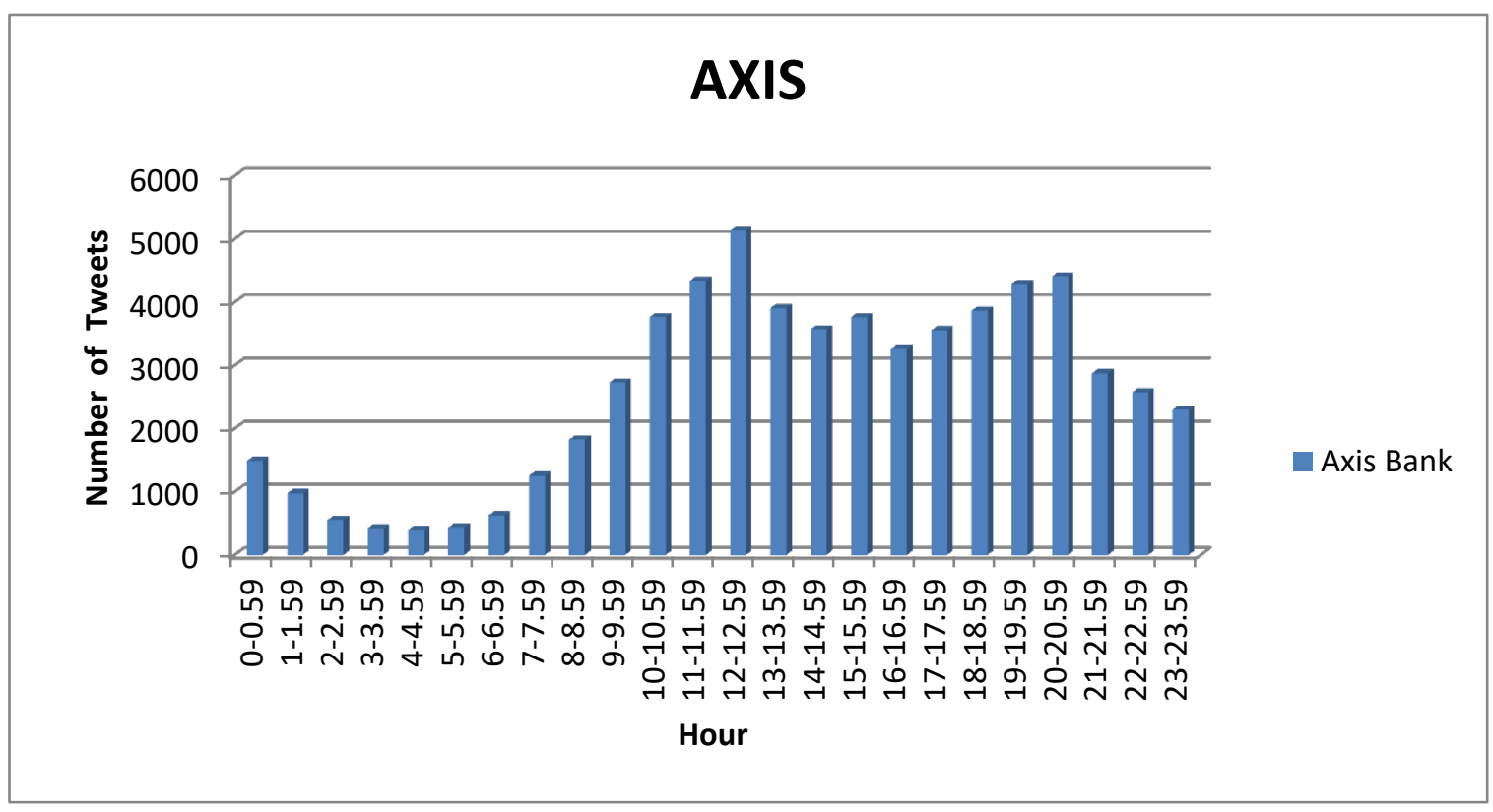

Figure 7: Hour wise overallTweets for AXIS 
Figures 9 \& 10 show that for HDFC maximum Tweets (overall and negative) have been tweeted between 13.00-13.59 while 4.00-4.59 has registered the lowest number of Tweets.

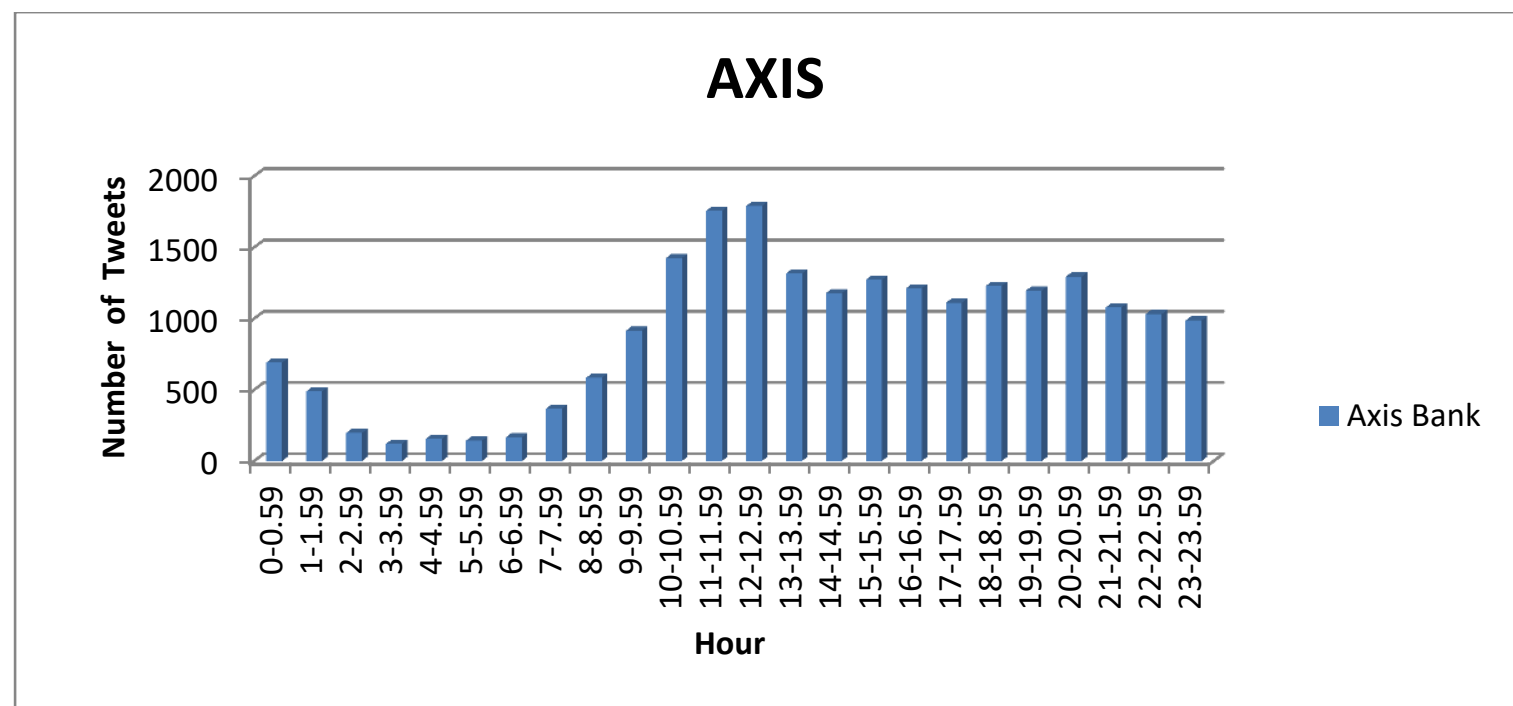

Figure 8: Hour wise negative Tweets for AXIS

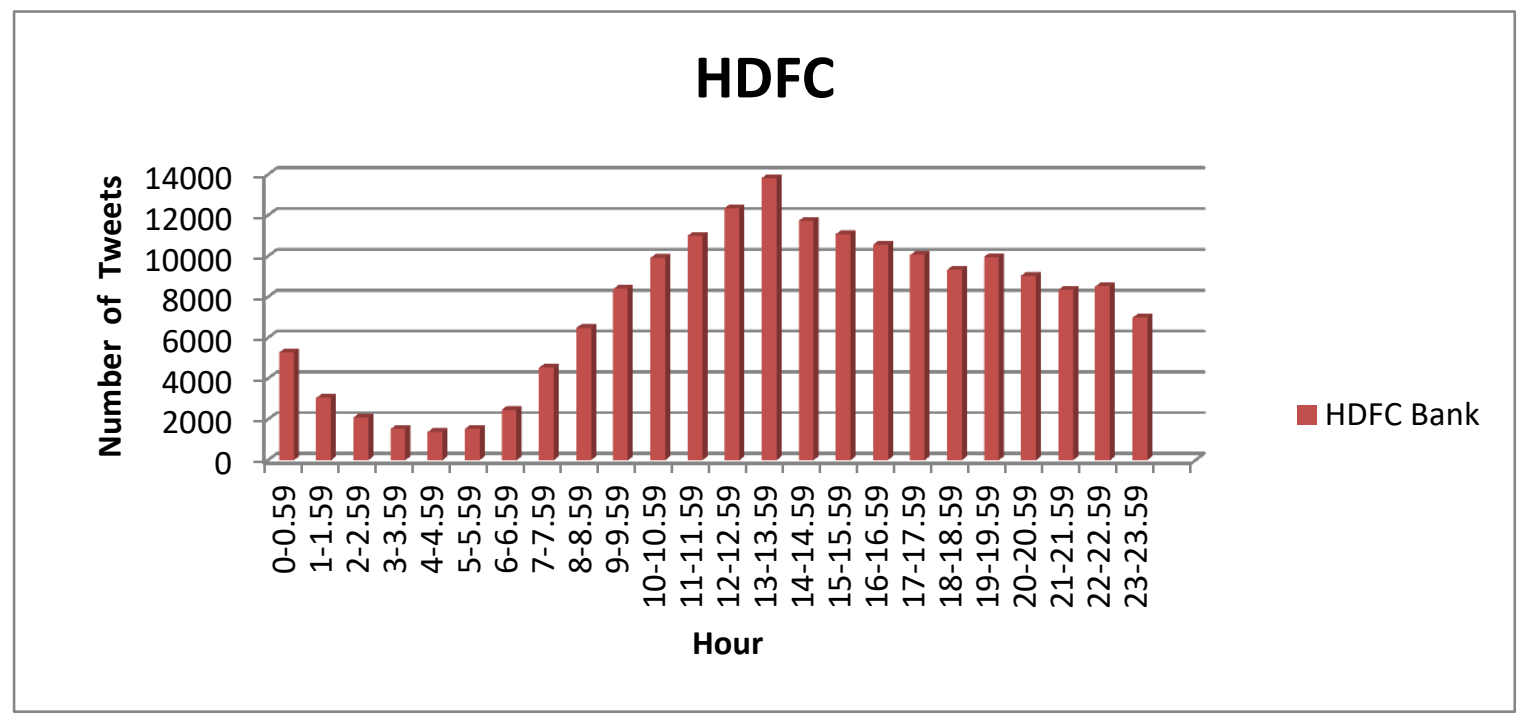

Figure 9: Hour wise overall Tweets for HDFC

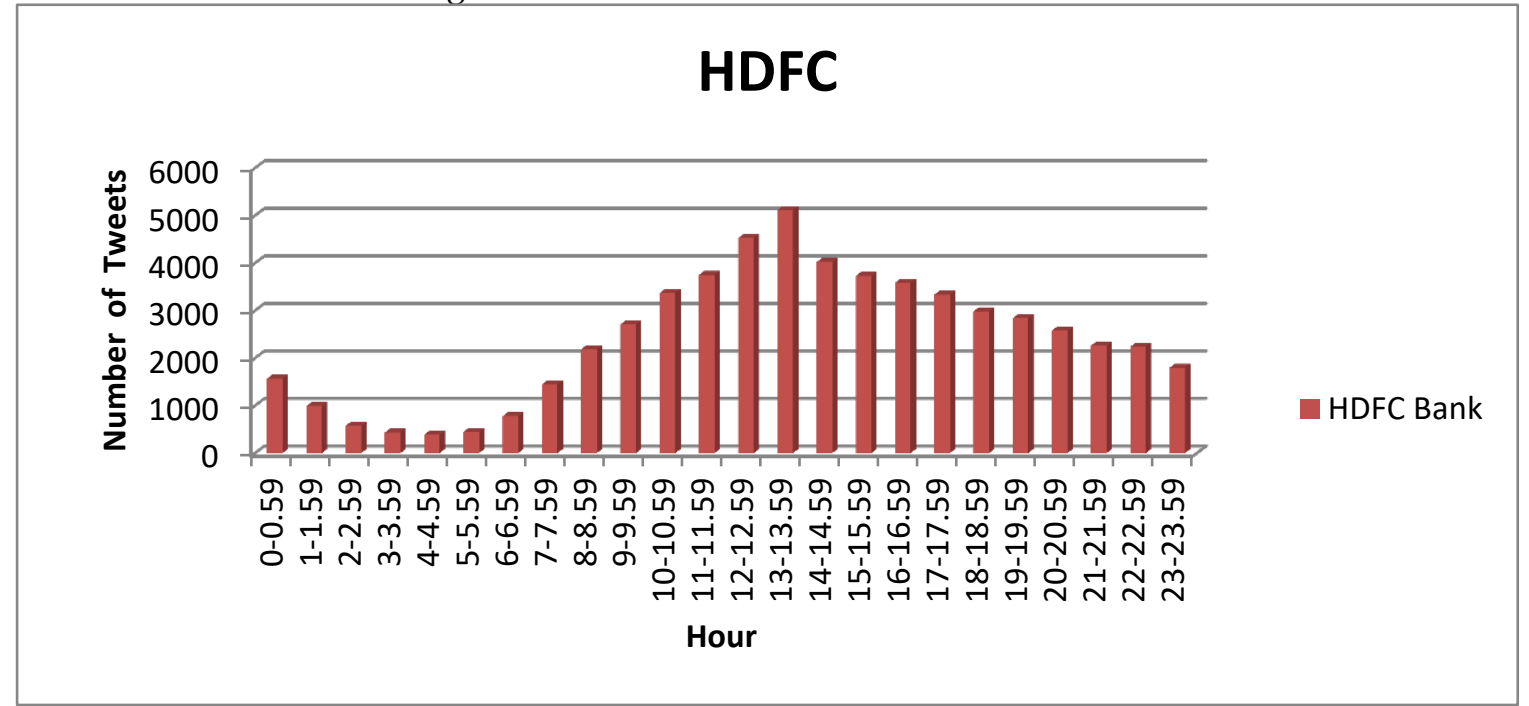

Figure 10: Hour wise negative Tweets for HDFC 
For ICICI , 17.00-17.59 is the peak hour for overall Tweets (Figure 11) whereas Figure 12 indicates that the Bank has received the maximum number of negative Tweets during 11.00-11.59 followed by 20.00-20.59 hours

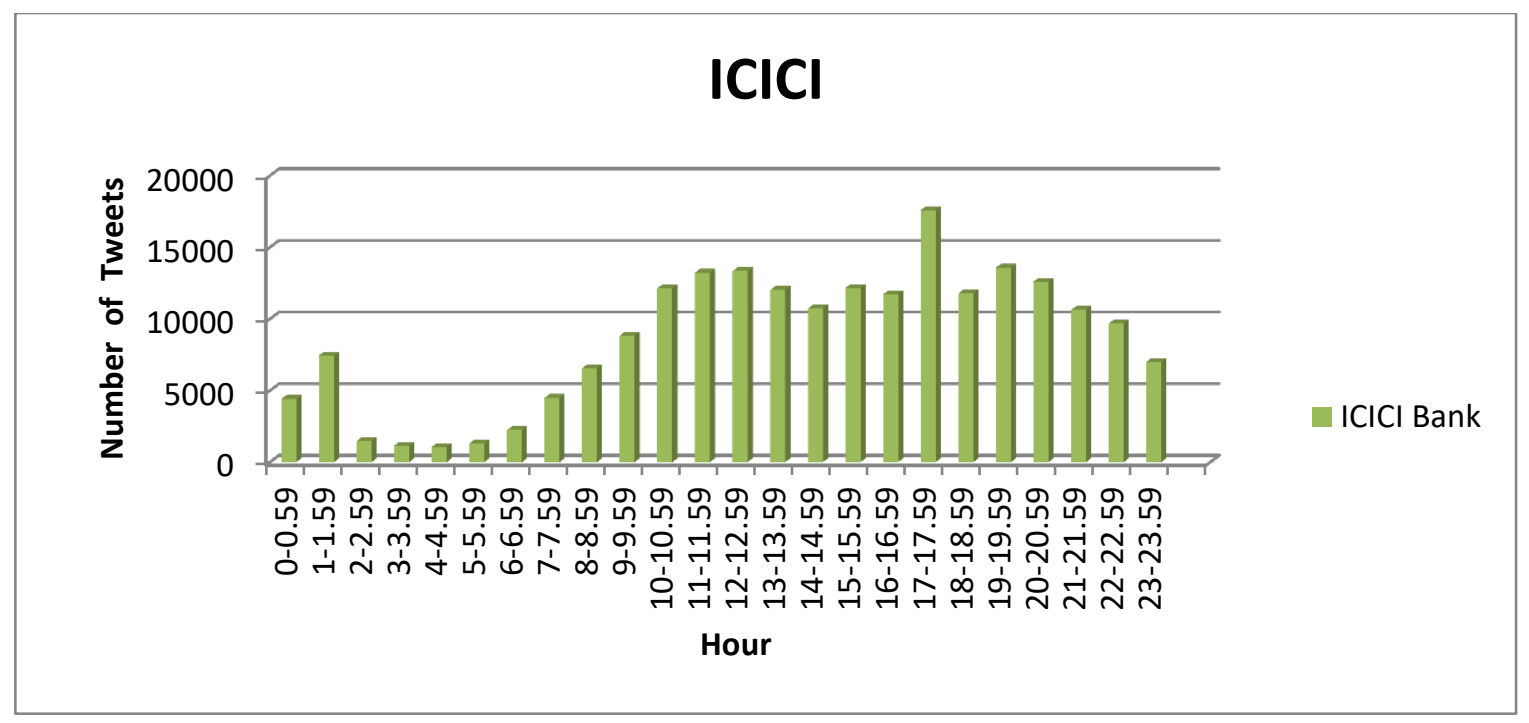

Figure 11: Hour wise overall Tweets for ICICI

\section{$\mathrm{ICICI}$}

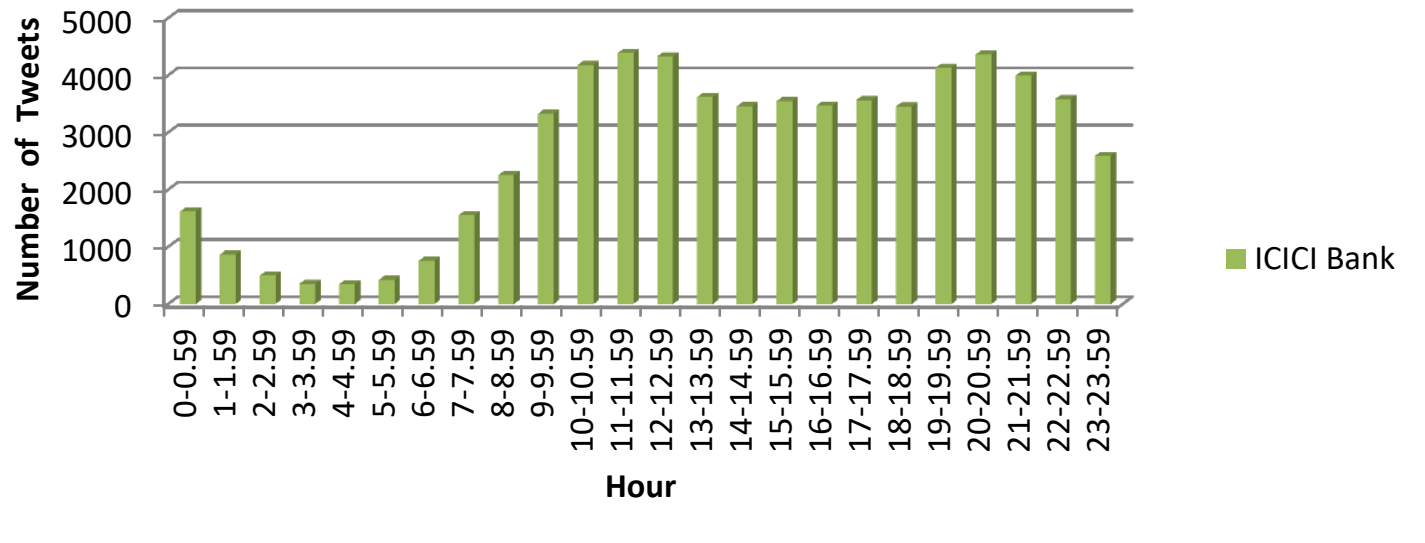

Figure 12: Hour wise negaive Tweets for ICICI

\section{KMB}

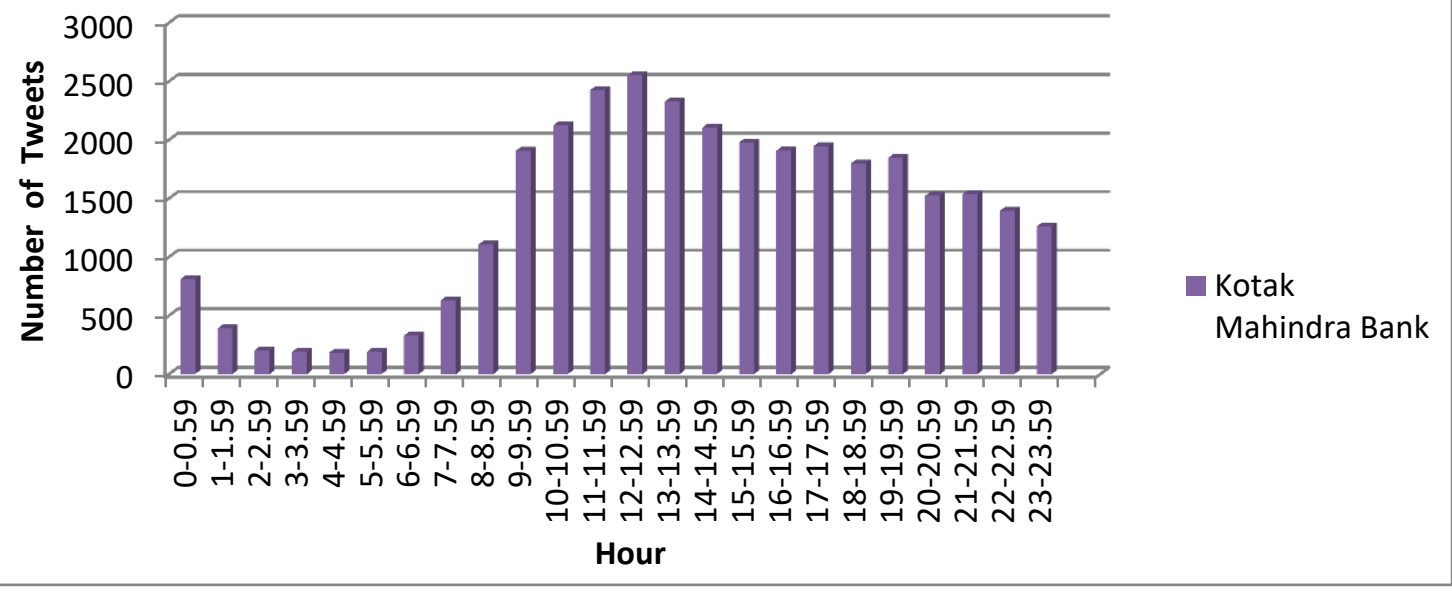

Figure 13: Hour wise overall Tweets for KMB 
KMB has received maximum overall Tweets between 12.00-12.59 and lowest during 4.004.59 hours (Figure 13).Duration 13.00-13.59 is the peak negative hour for the Bank followed by 12.00-12.59 hour (Figure 14)
Period 3.00-3.59 is the off-peak hour for YES (Figure 15) whereas 13.00-13.59 is the peak hour for overall Tweets. Figure 16 reveals that $10.00-10.59$ is the peak negative hour for the Bank closely followed by 11.00-11.59 hours.

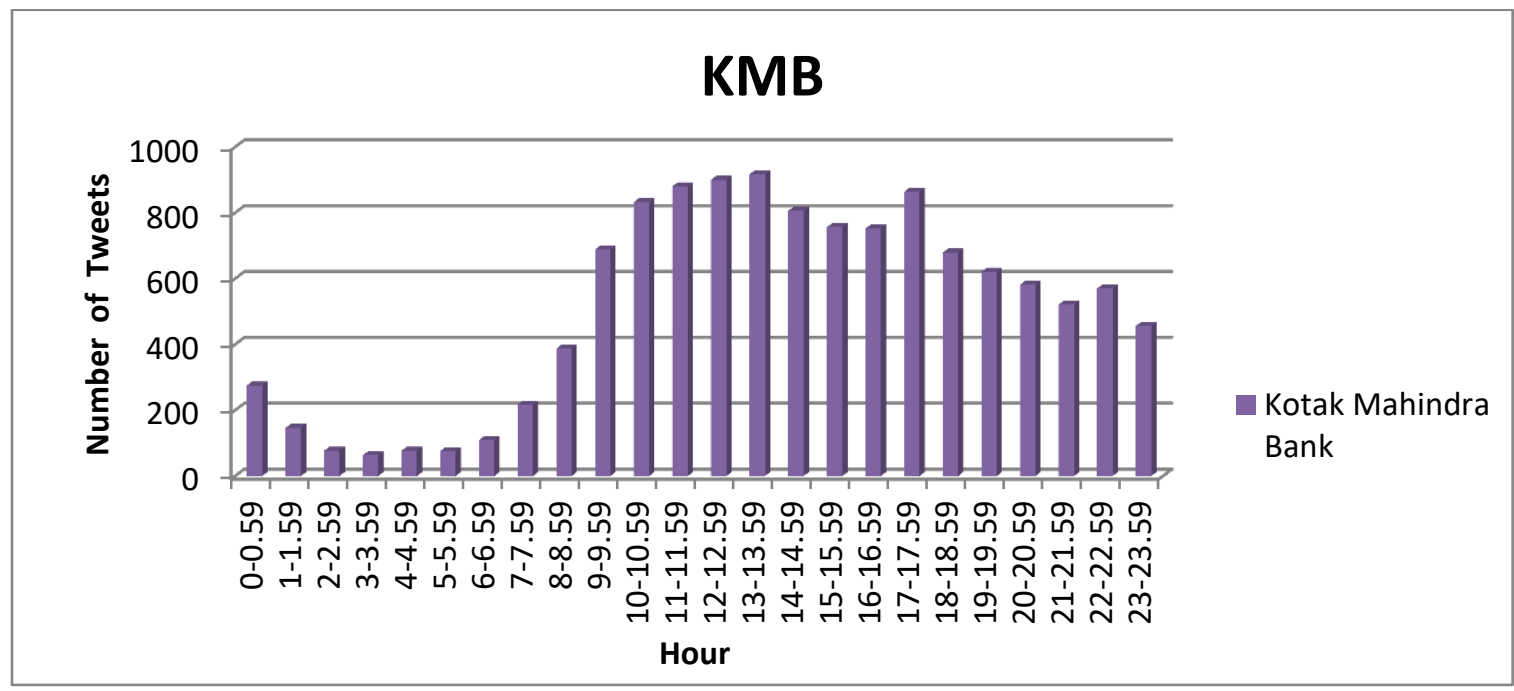

Figure 14: Hour wise negative Tweets for KMB

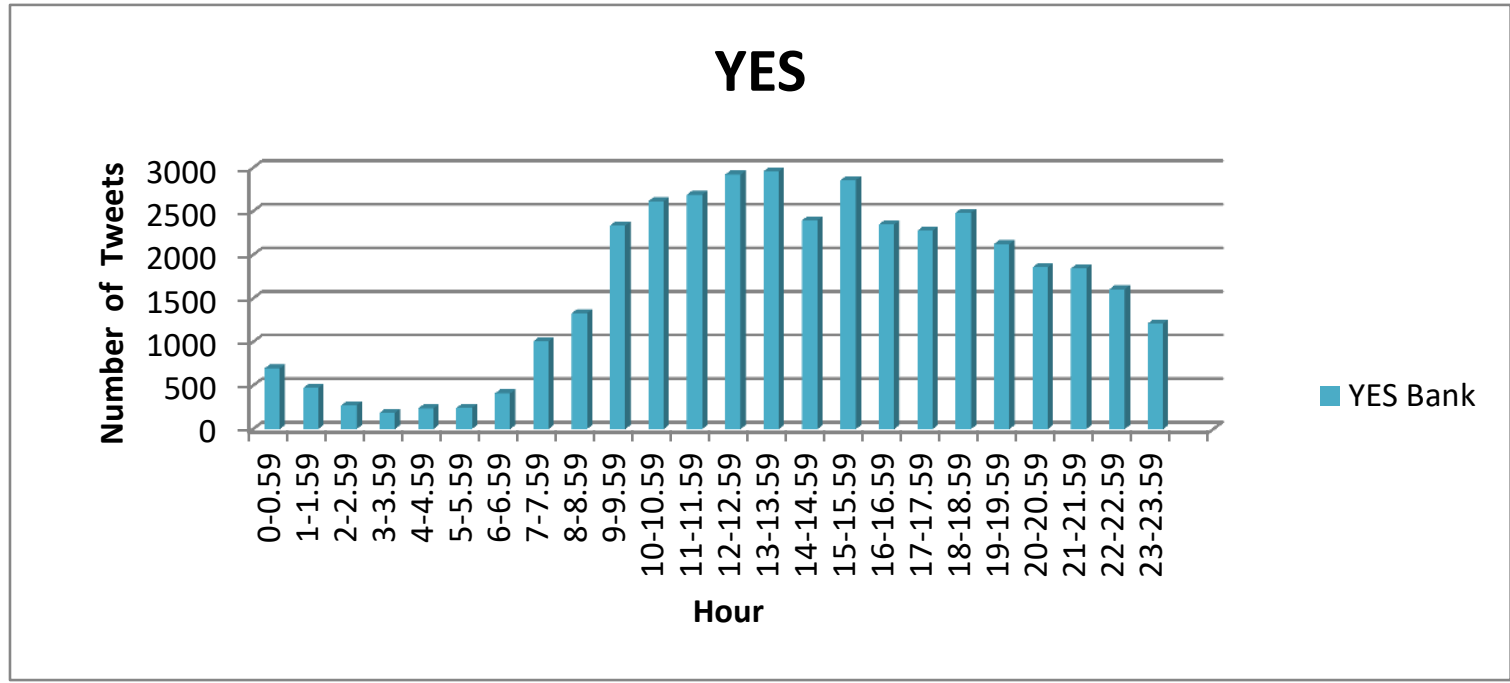

Figure 15: Hour wise overall Tweets for YES

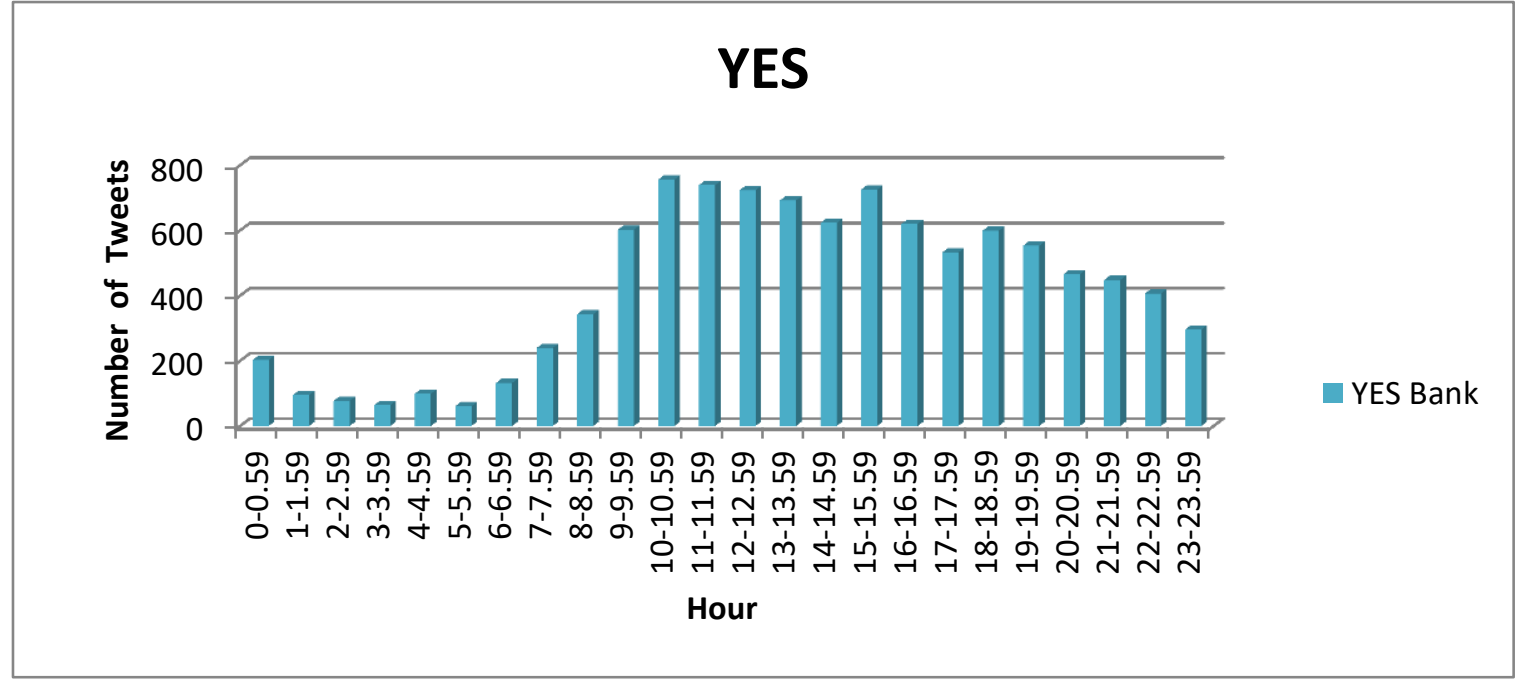

Figure 16: Hour wise negative Tweets for YES 


\section{Theoretical Implications}

The study is the first attempt in its kind to analyze customer behavior on Twitter for private sector Banks in India. Contrary to similar studies done in the past for other scenarios where analysis has been done on the limited number of Tweets or data obtained through surveys, findings of this study are based on a large number of Tweets (for a time duration of 06 months). Hence, study results reflect a broader perspective.

In past, few studies have analyzed how user sentiments on Twitter can be used to predict the activities on real-world like mood of $\backslash$ stock market, political opinion, etc. but on the contrary, this study has given a sense on how real-world business activities can also impact customer sentiments on Twitter which may lead to a larger online discussion around the brand.

\section{Managerial Implications}

The findings of this study hold great significance for the Banks' marketers about the use of Twitter as an effective medium for customer service management. Study results confirm that Bank customers are actively using Twitter to connect with their respective Banks and to share their grievances with other Twitter users. Results have revealed that it is extremely important to address negative Tweets as negative sentiments dominate over positive sentiments thus represent bias for negativity on Twitter (Nisar et al., 2018). Quick personalized responses, taking the conversation offline with the customers or conversations via Direct Messaging (DM) on Twitter to keep them "non-public", requesting customers to either delete the negative Tweet/s or Tweet positive acknowledgment, once the grievances are satisfactorily addressed / issue is resolved; are some of the ways to address them.

The study has also presented insights about timings of Tweets for each of the Banks which can further be used to strategize manpower planning and crucial support hours which supports the findings that the timely resolution of customer complaints makes them loyal customers (Tajuddin et al., 2020)

Word cloud drawn for positive and negative Tweets for the Banks can be used to identify customer satisfaction and service improvement area Considering the behavior of the Tweets, Banks can plan grievance tracking tools to discover unmarked Tweets. Also, a large number of Tweets have been only marked to Bank's primary/corporate Handles and to the top management (to Chairman only in the case of $\mathrm{KMB}$ ) which represents multiple scenarios viz Customer's unawareness for the presence of dedicated support Handle, Lack of confidence on support Handle's resolutions, Longer turn around time on the resolution by support Handle, customer's behavior of issue escalation to the Bank's top management. Bank marketers can plan customer surveys/feedback to determine the reasons for such behavior to take corrective measures.

\section{LIMITATIONS AND FUTURE SCOPE OF WORK}

This study has not examined the relationship between the number of Tweets "impressions" vis a vis Tweet sentiments which is an important factor from customer service management and marketing perspective. Also, researchers can investigate if real-world activities can scientifically predict users'sentiments on Twitter

\section{CONCLUSION}

For Banks, Twitter is primarily a customer service management platform than an information-sharing platform. Sentiment analysis of Tweets is a vital source of information related to customer behavior which can be used to make business-related decisions. Timely detection of Tweets is also extremely important to control the spread of negative discussion around the brand. The study has also highlighted that business activity in the real world impact user sentiments on Twitter hence in the event of a crisis or unpopular business developments, Bank marketers can expect the enhanced flow of negative sentiments on Twitter.

\section{REFERENCES}

Afshar, A., Polas, R. H., Imtiaz, M., \& Saboor, A. (2019). Customer care service management is moving forward to achieve sustainable customer retention in every industry. Does it play a role to increase brand rentention?International Journal of Management, 8(2), 88-97

Ahsan, M., Kumari, M., \& Sharma, T. P. (2019). Detection of context-varying rumors on 
Twitter through deep learning. Int. J. Adv. Sci. Technol, 128, 45-58

Alton, L. (n.d.). 4 tips for providing effective customer support on Twitter. Retrieved November 20, 2019, from https:// business.twitter.com/en/blog/4-tipsfor-providing-effective-customer-support-onTwitter.html

Alwagait, E., \& Shahzad, B. (2014). When are Tweets Better Valued? An Empirical Study. J. UCS, 20(10), 1511-1521

Are you looking for?... (2017, November 30). Retrieved December 21, 2019, from https://www.yesBank.in/media/pressreleases/yes-Bank-adjudged-Bank-of-theyear-india-2017-by-the-Banker-london

Baird, C. H., \& Parasnis, G. (2011). From social media to social customer relationship management. Strategy \& leadership

Bary, E. (2020, February 6). Twitter stock soars toward best day since 2017 after big beat on user growth. Retrieved April 29, 2020, from https://www.marketwatch.com/story/twitte r-stock-gains-after-first-1-billion-revenuequarter-big-user-growth-beat-2020-02-06

Bennett, D., \& Higgins, M. (1988). Quality means more than smiles. ABA Banking journal, 80(6), 46

Bhattacharyya, M., \& Roy, P. (2016). Engaging Social Media in Health Communication- Scope and Challenges of the 21st Century. Journal of Content, Community \& Communication, 3, 38-43.

Bhaskar PV (2004). Customer Service in Banks IBA Bulletin, 36(8): 9-13

Bollen, J., Mao, H., \& Zeng, X. (2011). Twitter mood predicts the stock market. Journal of computational science, 2(1), 1-8

Borate, N. (2019, June 18). Is HDFC Mutual Fund's FMP bailout unfair to other investors, shareholders? Retrieved May 1, 2020, from https://www.livemint.com/mutual-fund/mfnews/is-hdfc-mf-s-fmp-bailout-unfair-toother-investors-shareholders1560872410082.html

Breidbach, C., Choi, S., Ellway, B., Keating, B. W., Kormusheva, K., Kowalkowski, C., \& Maglio, P. (2018). Operating without operations: how is technology changing the role of the firm? Journal of Service Management.

Cairns, I. (2016, February 18). Making customer service even better on Twitter. Retrieved November 22, 2019, from https://blog.twitter.com/marketing/en_us/a /2016/making-customer-service-even-betteron-twitter.html

Chaoprasert, C., \& Elsey, B. (2004). Service quality improvement in Thai retail banking and its management implications. ABAC Journal, 24(1)

Chaturvedi, A. (2016, December 28). Twitter partners with ICICI Bank for advanced customer care. Retrieved December 21, 2019, from

https://economictimes.indiatimes.com/indus try/Banking/finance/Banking/twitterpartners-with-icici-Bank-for-advancedcustomer-

care $/$ articleshow $/ 56218076 . \mathrm{cms}$ ?from $=\mathrm{mdr}$

Christopher, M., Payne, A., \& Ballantyne, D. (1991). Relationship marketing: bringing quality customer service and marketing together

Cronin Jr, J. J., \& Taylor, S. A. (1992). Measuring service quality: a reexamination and extension. Journal of marketing, 56(3), 5568

Day, R. L., \& Landon, E. L. (1977). Toward a theory of consumer complaining behavior. Consumer and industrial buying behavior, 95(1), 425-437.

Dwivedi, A., Johnson, L. W., Wilkie, D. C., \& De Araujo-Gil, L. (2019). Consumer emotional brand attachment with social media brands and social media brand equity. European Journal of Marketing

Employees face action over insensitive comments on Pulwama attack. (2019, February 15). Retrieved from https://telanganatoday.com/employees-faceaction-over-insensitive-comments-onpulwama-attack

Felix, R. (2017). Service quality and customer satisfaction in selected banks in Rwanda. Journal of Business \& Financial Affairs, 6(1), 111

Fortin, D., Uncles, M., Burton, S., \& Soboleva, A. (2011). Interactive or reactive? Marketing with Twitter. Journal of Consumer Marketing 
Gavval, R., \& Ravi, V. (2020). Clustering Bank Customer Complaints on Social Media for Analytical CRM via Multi-objective Particle Swarm Optimization. In Nature Inspired Computing for Data Science (pp. 213-239). Springer, Cham

Goffin, K., \& Price, D. (1996). Service documentation and the biomedical engineer: Results of a survey

Gruen, T. W., Osmonbekov, T., \& Czaplewski, A. J. (2006). eWOM: The impact of customerto-customer online know-how exchange on customer value and loyalty. Journal of Business research, 59(4), 449-456

Guercini, S., Misopoulos, F., Mitic, M., Kapoulas, A., \& Karapiperis, C. (2014). Uncovering customer service experiences with Twitter: the case of airline industry. Management Decision

Halstead, D. (2002). Negative word of mouth: substitute for or supplement to consumer complaints? Journal of Consumer Satisfaction, Dissatisfaction and Complaining Behavior, 15, 1.

HDFC tops Forbes' list of best Indian banks, SBI not even in top 10. (2019, April 13). Retrieved December 21，2019， from https://www.businesstoday.in/topstory/hdfc-tops-forbes-list-of-best-indianBanks-sbi-not-even-in-top10/story/336972.html

Hidayanti, I., Herman, L. E., \& Farida, N. (2018). Engaging customers through social media to improve industrial product development: the role of customer co-creation value. Journal of Relationship Marketing, $17(1), 17-28$

Hoyer, W. D., Macinnis, D. J., \& Pieters, R. (2001). Customer behavior. Boston, Houghton Mifflin Company

Hu, X., Tang, L., Tang, J., \& Liu, H. (2013, February). Exploiting social relations for sentiment analysis in microblogging. In Proceedings of the sixth ACM international conference on Web search and data mining (pp. 537-546)

Huang, W. (2015, December 7). Consumers spend after positive customer service interaction on Twitter. Retrieved November 22, 2019, from https://blog.twitter.com/marketing/en_us/t
opics/research/2015/Consumers-spend-afterpositive-customer-service-interaction-onTwitter.html

Intro to Twitter for Business. (2016). Retrieved November 22, 2019, from https://business.twitter.com/en/basics/intro -twitter-for-business.html

Jamal, A., \& Naser, K. (2002). Customer satisfaction and retail banking: an assessment of some of the key antecedents of customer satisfaction in retail banking. International journal of bank marketing

Jansen, B. J., Zhang, M., Sobel, K., \& Chowdury, A. (2009). Journal of the American society for information science and technology, 60(11), 2169-2188

Kochukalam, C., Thomas, J., \& Joseph, M. B. (2018). Factors Influencing Choice of Banks in a Millennial Customer Perspective. Global Journal of Commerce and Management Perspective, 7(1), 1-6

Kwak, H., Lee, C., Park, H., \& Moon, S. (2010, April). What is Twitter, a social network or a news media?. In Proceedings of the 19th international conference on World wide web (pp. 591-600)

Leek, S., Houghton, D., \& Canning, L. (2019). Twitter and behavioral engagement in the healthcare sector: An examination of product and service companies. Industrial Marketing Management, 81, 115-129

Lesser, J. (2015, July 17). How Twitter data can play a role in customer service. Retrieved November 22, 2019, from https://blog.twitter.com/en_us/a/2015/how -twitter-data-can-play-a-role-in-customerservice.html

Lin, Y. (2019, November 30). 10 Twitter Statistics Every Marketer Should Know in 2020 [Infographic]. Retrieved December 19, 2019, from https://www.oberlo.in/blog/twitter-statistics

Liu, X., Burns, A. C., \& Hou, Y. (2017). An investigation of brand-related user-generated content on Twitter. Journal of Advertising, 46(2), 236-247

Ma, L., Sun, B., \& Kekre, S. (2015). The Squeaky Wheel Gets the Grease-An empirical analysis of customer voice and firm intervention on Twitter. Marketing Science, 34(5), 627-645 
Maecker, O., Barrot, C., \& Becker, J. U. (2016). The effect of social media interactions on customer relationship management. Business Research, 9(1), 133-155

Malhotra, C. K., \& Malhotra, A. (2016). How CEOs can leverage twitter. MIT Sloan Management Review, 57(2), 73

Masri, M., Esber, D., Sarrazin, H., \&amp; Singer, M. (2015, July 15). Your Company Should Be Helping Customers on Social. Retrieved December 20, 2019, from https://hbr.org/2015/07/your-companyshould-be-helping-customers-on-social

Meltzer, M. (2001). Customer retention and acquisition for telecommunications. Active Management Techniques, 14(1), 79-89

Mishra, J. K. (2007). Constituent dimensions of customer satisfaction: a study of nationalised and private banks. Revista tinerilor economişti, (08), 40-47

Moore, H., \&amp; Roberts, D. (2013, April 23). AP Twitter hack causes panic on Wall Street and sends Dow plunging. Retrieved November 20, 2019, from https://www.theguardian.com/business/201 3/apr/23/ap-tweet-hack-wall-street-freefall

Mukherjee, J. (2019, January 30). ICICI Bank sacks Chanda Kochhar, to recover bonuses. Retrieved May 1, 2020, from https://www.fortuneindia.com/enterprise/tr ouble-mounts-for-chanda-kochhar/102915

Nisar, T. M., \& Prabhakar, G. (2018). Trains and Twitter: Firm generated content, consumer relationship management and message framing. Transportation Research Part A: Policy and Practice, 113, 318-334

Nwulu, C. S., \& Nwokah, N. G. (2018). Customer Service Management and Marketing Performance of Food and Beverage Manufacturing Firms in Nigeria. International Journal of Social Sciences and Management Research, 4(8), 79-89

Pande, H. (2019, May 9). Cyclone Fani: HDFC Bank to restore 20 schools in Odisha. Retrieved May 1, 2020, from https://kalingatv.com/state/cyclone-fanihdfc-bank-to-restore-20-schools-in-odisha/

Pak, A., \& Paroubek, P. (2010, May). Twitter as a corpus for sentiment analysis and opinion mining. In LREc (Vol. 10, No. 2010, pp. 13201326)
Parasuraman, A., Berry, L. L., \& Zeithaml, V. A. (1991). Understanding customer expectations of service. Sloan management review, 32(3), 39-48

Paul, J., Mittal, A., \& Srivastav, G. (2016). Impact of service quality on customer satisfaction in private and public sector banks. International Journal of Bank Marketing.

Picazo, S. (2016, September 19). Customer Service on Twitter and the impact on brands. Retrieved November 21，2019, from https://blog.twitter.com/marketing/en_gb/a /en-gb/2016/customer-service-on-twitterand-the-impact-on-brands.html

Rosen, A., \& Ihara, I. (2017, September 26). Giving you more characters to express yourself. Retrieved December 20, 2019, from https://blog.twitter.com/en_us/topics/prod uct/2017/Giving-you-more-characters-toexpress-yourself.html

Sakaki, T., Okazaki, M., \& Matsuo, Y. (2010, April). Earthquake shakes Twitter users: realtime event detection by social sensors. In Proceedings of the 19th international conference on World wide web (pp. 851-860)

Savage, N. (2010). New search challenges and opportunities. Communications of the ACM, 53(1), 27-28

Socialbakers. (n.d.). Most popular Twitter accounts in India. Retrieved January 22, 2020, from

https:// www.socialbakers.com/statistics/twit ter/profiles/india/brands/finance/bank

Soltani, Z., Zareie, B., Milani, F. S., \& Navimipour, N. J. (2018). The impact of the customer relationship management on the organization performance. The Journal of High Technology Management Research, 29(2), 237-246

Stauss, B., \& Seidel, W. (2019). Social Media Complaints. In Effective Complaint Management (pp. 451-468). Springer, Cham

Taecharungroj, V. (2017). Starbucks' marketing communications strategy on Twitter. Journal of Marketing Communications, 23(6), 552-571

Tajuddin, W. N. S. W. A., \& Nayan, S. M. (2020). Rising customer satisfaction. Journal of Undergraduate Social Science and Technology, 2(2). 
Thelwall, M., Buckley, K., \& Paltoglou, G. (2011). Sentiment in Twitter events. Journal of the American Society for Information Science and Technology, 62(2), 406-418

Top Companies in India by Total Assets - BSE. (n.d.). Retrieved January 22, 2020, from https://www.moneycontrol.com/stocks/mar ketinfo/totassets/bse/bank-private.html

Tripathi, S. (2019). Impact of Social Media on Generation $Y$ for Buying Fashion Apparel. Journal of Content, Community \& Communication, 105-113

Tumasjan, A., Sprenger, T. O., Sandner, P. G., \& Welpe, I. M. (2010, May). Predicting elections with twitter: What 140 characters reveal about political sentiment. In Fourth international AAAI conference on weblogs and social media

Uppal, R. K. (2010). Customer complaints in banks: Nature, extent and strategies to mitigation. Journal of Economics and International Finance, 2(10), 212-220

Vomhof Jr, J. (2013, May 7). Best Buy scraps Twelpforce, shifts Twitter support to Geek
Squad. Retrieved November 22, 2019, from https://www.bizjournals.com/twincities/ne ws/2013/05/07/ best-buy-scraps-itstwelpforce.html

Wakefield, L. T., \& Wakefield, R. L. (2018). Anxiety and ephemeral social media use in negative eWOM creation. Journal of Interactive Marketing, 41, 44-59

Wallace, P. (2014, February 3). The Top 500 Banking Brands, 2014. Retrieved December 21, 2019, from https:// www.thebanker.com/BankerData/Banker-Rankings/The-Top-500Banking-Brands-2014?ct=true

Wauters, R. (2009, July 21). Best Buy Goes All Twitter Crazy With @Twelpforce. Retrieved November 22, 2019, from https://techcrunch.com/2009/07/21/bestbuy-goes-all-twitter-crazy-with-twelpforce/

Xu, A., Liu, Z., Guo, Y., Sinha, V., \& Akkiraju, R. (2017, May). A new chatbot for customer service on social media. In Proceedings of the 2017 CHI Conference on Human Factors in Computing Systems (pp. 3506-3510) 